\title{
Induced Innovation and Energy Prices
}

\author{
David Popp \\ The University of Kansas \\ October 14, 1998
}

\begin{abstract}
This paper uses U.S. patent data from 1970 to 1994 to study the impact of energy prices on energy-efficient innovations. Theories of technological change have focused both on demand-side factors, which spur innovative activity by increasing the value of new innovations, and supply-side factors, such as scientific advancements that make new innovations possible. Data on demand-side factors are easily obtained, but data on supply-side factors that influence innovation are not readily available. This paper uses patent citations as a measure of the usefulness of the existing base of scientific knowledge. Citations to previous patents are used to construct productivity estimates, which measure the usefulness of the existing stock of knowledge to inventors in a given energy field for any given year. These estimates are then combined with data on demand-side factors to estimate a model of induced innovation in energy technologies. The results indicate that both energy prices and the supply of knowledge have strongly significant positive effects on innovation. The paper concludes with a discussion of the implication of this work for environmental policy.
\end{abstract}

The author would like to thank William Nordhaus, Joel Waldfogel, Robert Evenson, Ariel Pakes, Deitrich Earnhart, Paul Willen and two anonymous referees for helpful comments. Despite their useful suggestions, however, all mistakes are solely the responsibility of the author. In addition, the assistance of Adam Jaffe, who provided the programming code for the patent citation regressions, is gratefully acknowledged. Finally, thanks to Robert Evenson, Jon Putnam, and Samuel Kortum for their help in obtaining patent data. Partial financial support for this paper comes from DOE grant 593A3140217. 
The process by which new technologies develop is a central question for economic theory, as well as for public policy. Nonetheless, as economists, our understanding of the process is limited. Theories of technological change have focused both on demand-side factors, which spur innovative activity by increasing the value of new innovations, and supply-side factors, such as scientific advancements that make new innovations possible. This paper uses patent data from the United States to study the role of both demand- and supply-side factors in the development of energy-efficient technologies since 1970. I show that it is possible to use patent citation data to construct a measure of the supply-side factors that influence innovation. This measure is helpful in explaining inventive activity, as it tends to control for diminishing returns to research over time.

Understanding the factors that influence energy-efficient innovations is important for environmental policy. Many of the environmental problems facing the world today, such as global warming, are long-term problems that technological progress may play a crucial role in ameliorating. However, most climate change models treat technological change as exogenous. ${ }^{1}$ As a result, they miss the important link between policy and technological change. ${ }^{2}$ One reason for leaving out induced innovation is that there is little empirical evidence on induced innovation

\footnotetext{
${ }^{1}$ Two recent exceptions are Goulder and Schneider (forthcoming) and Nordhaus (1997). As evidence that there is still much work to be done in correctly modeling induced technological change, the two papers reach opposite conclusions about the effect that induced innovation from a carbon tax can have on reducing emissions.

${ }^{2}$ This observation is made even more relevant by the recent negotiations at the Kyoto conference on climate change. The Clinton administration has made reliance on technological advancements a cornerstone of any action taken on global warming. However, the administration has not provided strong support for policies, such as a carbon tax, that would likely lead to increased innovation.
} 
and environmentally friendly technology. ${ }^{3}$ This paper aims to fill that gap. ${ }^{4}$

The paper begins with a review of the economic literature on the sources of technological advancement. Section II details the construction of the energy patent data set used in the paper and discusses how the data will be used in the regressions that follow. In section III, patent citation data are used to develop estimates of the usefulness of the knowledge contained in patents granted in different years. These estimates are used in section IV, along with the rest of the data in section II, to test the importance of both demand and supply side influences in the development of new energy technologies. Both energy prices and the supply of knowledge available to the inventor are found to have a significant effect on the level of energy-saving innovation. The paper concludes by discussing the implication of these results for both environmental policy and the economics of technological change.

\section{Induced Innovation and the Supply of Knowledge}

Although the main focus of this paper is the influence of energy prices on innovative activity related to energy-efficiency, a more general question lies behind it: what factors influence inventive activity? The hypothesis that higher energy prices lead to the development of more energy-saving technologies is derived from demand-pull theories of innovation. Higher energy prices make energy-efficient inventions more valuable, either because larger energy savings (in dollar terms) occur, or because the market for energy-efficient inventions will be

\footnotetext{
${ }^{3}$ For example, Goulder and Schneider (forthcoming) state that their "ability to generate more precise estimates [of the contribution of induced innovation] is fundamentally limited by the absence of empirical estimates on the relationships between R\&D expenditure and technological change."

${ }^{4}$ The existing empirical literature on induced environmental innovation includes Lanjouw and Mody (1996), Jaffe and Palmer (1997), and Newell, Jaffe, and Stavins (1998). However, only Jaffe and Palmer include elasticities that could be incorporated into large scale models of the environment.
} 
larger. Other theories of innovative activity focus on the role that existing scientific knowledge plays in determining the pace and direction of technological change. These are referred to as technology-push theories.

The demand-pull theory most relevant to this paper is the induced innovation hypothesis. The induced innovation literature highlights the role of factor prices in determining the pace of technological change. The induced innovation literature became influential after papers by Ahmad (1966) and Kamien and Schwartz (1968). Binswanger (1974, 1978a, 1978b) introduced uncertainty to the induced innovation literature by adapting the stochastic model of Evenson and Kislev (1975). The main results of Binswanger are that an increase in the expected total cost of a factor leads to an increase in $\mathrm{R} \& \mathrm{D}$ focused on reducing use of that factor, and that a decline in the productivity of $R \& D$ to conserve a factor leads to a decrease in $R \& D$ on conserving the factor.

The induced innovation hypothesis focuses on the impact of factor prices on the direction R\&D will take, but it does not address convincingly the question of how new knowledge is developed. The induced innovation literature relies on an innovation possibilities frontier (IPF) that maps the amount of research spending on various factors to new knowledge related to those factors. The IPF, illustrated in Figure 1, can be seen as a production function for new knowledge. However, the induced innovation literature says little about where the IPF comes from. By ignoring the determinants of the IPF, the induced innovation hypothesis does not truly endogenize the path of technological change (Nordhaus 1973). In particular, the research performed in the field of energy in a given year may help determine how successful future energy research is likely to be. If diminishing returns to research exist, increases in the current level of R\&D may make future R\&D more difficult. By ignoring the formation of the IPF, there is no tradeoff between current research on a factor and the productivity of future research on the factor. 
Although ignored by the induced-innovation literature, the knowledge available to researchers should play an important role in determining the direction of technological change. Even if energy prices are high, rational investors will not invest research dollars into energyefficient research if the prospects of success are unlikely. The technology-push theories of technological change, primarily advanced by Rosenberg (1982, 1994), focus on the importance of the existing base of scientific knowledge to new inventions. Technological advances make new inventions possible, and it is these breakthroughs that influence the direction of technological change. For example, the invention of microcomputer chips led to the development of a generation of electronic equipment. Emphasizing the importance of technological opportunity, Mowrey and Rosenberg (1979) write:

Rather than viewing either the existence of a market demand or the existence of a technological opportunity as each representing a sufficient condition for innovation to occur, one should consider them each as necessary, but not sufficient, for innovation to result; both must exist simultaneously. (Emphasis added.)

By using patent citation data as a measure of technological opportunity, the current paper is able to combine information on both market demand and technological opportunity in an empirical study of the determinants of research and development.

\section{Modeling \& Data}

Combining the demand-side and supply-side theories of technological change suggests that energy-saving research, $R_{t}$, is a function of both expected energy prices and the usefulness of the existing stock of scientific knowledge. The more useful existing knowledge is - that is, the more potential scientific breakthroughs that it suggests - the higher the marginal productivity of research inputs will be. Since data on energy R\&D expenditures are sketchy at best, counts of 
energy patents will be used as the dependent variable. ${ }^{5}$ A data set of patents in 22 energy-related fields was constructed for this purpose. Section IIA discusses the construction of this data set. Section IIB discusses how the patent data will be used to estimate the effects of energy prices on energy R\&D.

\section{A. The Energy Patent Data Set}

One of the major contributions of this paper is the creation of a data set of energy patents in the United States from 1970-1994. Despite the theoretical advances of the induced innovation literature during the 1960's and 1970's, sufficient data to test the hypotheses were unavailable. Data on R\&D expenditures were then, as they are now, unavailable for specific types of research. ${ }^{6}$ In addition, the computerization of patent data, which makes the construction of this data set possible, has occurred only over the past ten years. As a result, most existing tests of the induced innovation hypothesis are indirect tests. These tests focused on the results of innovation - actual use of factors - rather than the innovation process itself.

By comparison, this paper takes advantage of improved data sources, especially in the realm of patent data, to develop a direct test of the induced innovation hypothesis. The energy patent database assembled for this paper contains over 40,000 patents. This section discusses the data used in this paper, beginning with the creation of the patent data set. Other data used in the paper are discussed in appendix A.

\footnotetext{
${ }^{5}$ Although some data on energy R\&D is available from the National Science Foundation, it is at the industry, rather than technology level, and there are many years with missing observations due to rules on disclosure of private information.

${ }^{6}$ Although the NSF does provide detailed industry-level R\&D statistics, it is difficult to deduce from those numbers the different types of R\&D being done. For example, in the field of agriculture, where most induced innovation work has been done, agriculture $R \& D$ could focus on labor-saving devices, new fertilizers that increase the productivity of land, new pesticides, etc. Using patent data allows these distinctions to be made.
} 
When a patent is granted in the United States, it is given a U.S. classification number. There are over 300 main classification groups and over 50,000 subclassifications. The first step in assembling the data set for this paper was to identify subclassifications that pertain to energy efficiency. Using resources from the Department of Energy and from the academic sciences, I identified several areas of research in the energy field. Descriptions of these technologies were matched with U.S. patent subclassifications. Technologies for which no clear subclassification exists were eliminated. The resulting set of subclassifications was then sorted into 22 distinct technology groups to be used in this paper. The data set includes all patents granted in these subclassifications in the United States from 1970 to 1994. Appendix B provides general background information on the technologies. Appendix $\mathrm{C}$ lists the technology groups and the classifications included in each. The technology groups include 11 groups pertaining to energy supply, such as solar energy, and 11 relating to energy demand, such as methods of reusing industrial waste heat.

Using data from the MicroPatent CD-ROM database of patent abstracts and additional data from the U.S. Patent and Trademark Office, I identified all patents in the 22 technology groups that were granted in the U.S. between 1970 and $1994 .^{7}$ For the purposes of this paper, only patents granted to Americans are included, since foreign inventors are likely to be influenced by factors not included in the data described below. For each technology group, patents are sorted

\footnotetext{
${ }^{7}$ The MicroPatent database contains every U.S. patent issued from 1975-1994. It includes all of the information that is found on the front page of a patent, including the date of application, date of grant, name of the inventor and his or her organization, the nation of the patent holder, and citations to previous patents. Because the MicroPatent database begins in 1975, it does not extend far enough into the past to encompass the first energy crisis of 1973. The Classification and Search Support System (CASSIS), available from the U.S. Patent and Trademark Office, was used to obtain additional lists of patents in the target subclassifications, so that the data set in this paper extends backwards to 1970. Unfortunately, for the patents obtained from CASSIS, the additional data found on the MicroPatent database, such as patent citations, are not available.
} 
by the year of application. ${ }^{8}$ In the United States, information on patents is not made public until the patent is granted. Thus, only successful patent applications are included in the data set. Several papers have found that patents, grouped by the date of application, are a good indicator of R\&D activity (see Griliches (1990) for a survey). Since a patent application is only made public when a patent is granted, the data have been scaled up by using a distribution of the lag between patent application dates and patent grant dates for the patents in the sample. Because a large number of patents applied for in recent years have yet to be granted, and since recently granted patents have not had a chance to be cited yet, only patent applications through 1990 are used. ${ }^{9}$

Table 1 provides the annual patent count in each of the technology groups from 1970 to 1993. Figure 2 illustrates trends in the data for five of the technology groups. ${ }^{10}$ Included for reference in these figures is an index of energy prices. The index provides the cost of energy in 1987 dollars per million British thermal units (Btu). For most of the technology groups, there is a jump in patent applications during the energy crises of the 1970's, suggesting that energy prices do play an important role in inducing energy-efficient technological change. ${ }^{11}$ This relationship is further evident in Table 2, which presents the correlation between patent applications and energy prices. Note that the strongest correlations are with current energy prices, and that the effect of lagged energy prices drops quickly.

\footnotetext{
${ }^{8}$ Note that the patent application data is taken from the front page of the granted patent, and does not include the date of application of earlier continuations and divisions that may exist. A check of a random sample of patents in the data set indicates that about 20 percent of patents are affected. These patents would have earlier application dates than is given on the front page. Since each year contains patents that were erroneously assigned to it, rather than an earlier year, and omits patent applications that were filed but then continued in a later year, most of the error should cancel out. Any remaining error would bias the estimated elasticities downward slightly, since more incorrectly assigned patents would occur in years of heavy patenting activity, such as when energy prices are high. As I nonetheless find significant coefficients in the regressions, the effect of this error appears to be small.

${ }^{9}$ Based on the distribution of the lag between application and grant in this sample, 99 percent of the patents applied for in 1990 should have already been granted by 1994, the last year in the Micro Patent database.

${ }_{10}$ Additional figures are available from the author by request.
} 
In addition to illustrating the strong effect that energy prices have on patenting activity, Figure 2 also highlights the importance of considering the returns to R\&D. Note that energy prices do not peak until 1981. Nonetheless, patenting activity in most of these technology groups reaches its peak in the late 1970's. Had the returns to energy R\&D remained constant over time, we would expect patenting activity in these fields to remain high until prices began to fall. That patenting activity drops before prices do suggests that the possibility of diminishing returns to research should be explored. ${ }^{12}$ The use of patent citation data makes that possible.

\section{B. Modeling}

The data on successful energy patent applications will be used along with data on prices, the productivity of $R \& D$, federal $R \& D$ spending, and other exogenous variables described in appendix A to test the induced innovation hypothesis for energy research. Because much of the research and development process is poorly understood, specifying a structural model of the determinants of energy R\&D is difficult. Rather, a simple log-log form regression is used. Such a specification allows the resulting coefficients to be interpreted as elasticities, which can then be used by modelers of environmental problems such as global warming.

The dependent variable is the percentage of successful domestic patent applications per year that are in each technology field. Because we are interested in identifying the effect that federal R\&D spending has on increasing research efforts, patents held by government agencies

\footnotetext{
11 Notable exceptions include fuel cells, the use of waste as fuel, and continuous casting. Reasons why specific technologies may differ are discussed in appendix A.

12 One might argue that another possible explanation for the early decline in energy patents is that political support for energy R\&D may have changed. However, the drop in patenting occurs during the Carter years, when support for energy research was at its highest.
} 
are not included. Using the percentage of applications, rather than a raw count of applications, accounts for the changes in the total number of patents that have occurred due to growth in the economy or to exogenous changes in the value of patent protection. ${ }^{13}$

Define the following variables. Let $E P A T_{i, t}$ represent the number of successful non-

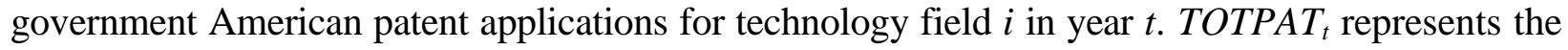
total number of successful non-government American patent applications in year $t . E\left[P_{E t+1}\right]$ is the expected price of energy in the next period. $\varphi_{R i t}$ represents the marginal productivity of research inputs. $\mathbf{Z}$ is a vector of other independent variables, such as R\&D spending by the U.S. Department of Energy, tax credits, and technology-specific variables. These variables are defined in appendix A. $N$ is the number of technologies under consideration, and $T$ is time. For any energy-saving technology, this paper estimates a model of the form:

$$
\begin{array}{r}
\log \left(\frac{E P A T_{i, t}}{\text { TOTPAT }_{t}}\right)=\mu_{i}+\lambda_{i} \log P_{E, t}+\rho \log P_{E, t-1}+\theta_{i} \log \varphi_{R i t}+\eta_{\mathbf{i}} \log \mathbf{Z}+\varepsilon_{i t}, \\
i=1, \ldots, N ; t=1, \ldots, T .
\end{array}
$$

Ideally, we would prefer to have the expected future price of energy in equation (1). Since we do not observe expected prices directly, current and lagged values of energy prices are used in place of expected prices. Because decisions on government funding of energy R\&D are correlated with energy prices, instrumental variables are used for federal energy R\&D spending. Lagged federal energy R\&D and a dummy variable representing the lagged political party of the President

\footnotetext{
${ }^{13}$ During the years studied in this paper, total domestic patent applications start at 54,894 in 1971, fall to a low of 31,548 in 1985 , and rise to 59,032 by 1990 .
} 
are used as instruments. ${ }^{14}$ Estimates of the marginal productivity of research are found by using data on patent citations. Section III discusses how citations will be used for this purpose.

Using patent data as a measure of research output poses several complications. The first is that the propensity to patent varies widely by industry. In some industries, such as the chemical industry, many new innovations are patented. In other industries, secrecy is a more important means of protection. In these industries, the cost of revealing an idea to competitors is often not worth the gains from patent protection. As a result, the correlation between R\&D and patents varies across industries. However, our interest lies more in the time series aspects of the data. It does not matter whether there are twice as many patents in one field as another. What does matter is whether the number of patents in each field increases with an increase in energy prices. As long as the tendency to patent remains the same in each field across time, variations in the tendency to patent across different fields will not pose a problem.

Unfortunately, the second difficulty with using patent data is that it is not clear that the tendency to patent is the same across time. Over time, the ratio of patents to R\&D expenditures has fallen in the United States (as well as in other industrialized nations). Some researchers, most notably Evenson (1991), consider the falling ratio evidence of diminishing returns to R\&D. ${ }^{15}$ Similarly, Kortum and Lerner (1997) argue that a recent upswing in patenting activity in the United States is due to the increasing fertility of new research opportunities. Other researchers,

\footnotetext{
${ }^{14}$ Federal funding for energy R\&D fell dramatically a year after President Reagan took office in 1981. A lagged value of the party is used to account for delays in the budgeting process. For example, the fiscal year 1981 budget would have been signed by President Carter before he left office.

${ }^{15}$ In this paper, diminishing returns to research refers to the expected return on the inputs to the research process, not the returns to the input. The notion that there are increasing returns to the output of knowledge, usually attributed to the public good nature of knowledge, is by no means compromised by claiming that the inputs to research experience diminishing returns. Diminishing returns to research simply implies that it becomes more and more difficult to acquire new knowledge as time progresses.
} 
most notably Griliches (1989), claim that research opportunities have not declined. Griliches argues that the fall in the patent-to- $R \& D$ ratio is due to changes in the willingness of inventors to patent new inventions. An exogenous fall in the willingness to patent would result in a falling patent-to-R\&D ratio even if the productivity of research spending remained the same.

The challenge raised by the falling patent/R\&D ratio is to determine the cause of the decline. It could stem either from changes in the perceived benefits of patents or from changes in the probability of success of R\&D. This paper takes two steps to help identify the cause. First, using the percentage of patent applications helps to correct for changes in the cost of patenting. Changes that affect all patent classifications will lead to a change in the total number of patent applications in a given year. Thus, by using a percentage of patent applications, exogenous changes in the propensity to patent are removed from the data.

The second step to identifying changes in patenting behavior over time is to include a measure of the marginal productivity of R\&D. A significant positive coefficient on the productivity of $R \& D$ suggests that the expected returns to $R \& D$ do play a role in determining the level of $R \& D$. As section III will show, the estimates of the marginal productivity of R\&D suggest that there are diminishing returns to $R \& D$ over time. Thus, a significant positive coefficient on the lagged productivity estimates suggests that diminishing returns to $R \& D$ explain at least part of the decline in the patent/R\&D ratio.

\section{Patent Citations and the Existing Stock of Knowledge}

We now turn to the empirical work necessary to study the determinants of energy R\&D. Before regressing patents on the determinants of $R \& D$, it is first necessary to develop estimates of the marginal productivity of knowledge. Patent citation data are used for this purpose. These 
estimates will be used in section IV to identify the effect of technology-push influences on energy efficient innovation.

This section begins by describing patent citations, and illustrating how they can be used as a measure of the productivity of R\&D. Then, to obtain estimates of the productivity of existing knowledge to inventors, a citation function developed by Adam Jaffe, and used in papers by Caballero and Jaffe (1993) and Jaffe and Trajtenberg (1995), is employed. This section summarizes both the procedure used and the results of the estimation of the citation function. See Popp $(1998,1997)$ for further details.

\section{A. Patent Citations and the Productivity of Research}

When a patent is granted, it contains several citations to earlier patents that are related to the current invention. The citations are placed in the patent after consultation between the applicant and the patent examiner. It is the applicant's responsibility to list any related previous patents of which he or she is aware. In addition, the examiner, who specializes in just a few patent classifications, will add other patents to the citations, as well as subtracting any irrelevant patents cited by the inventor. Patent citations narrow the reach of the current patent by placing the patents cited outside the realm of the current patent, so it is important that all relevant patents be included in the citations. ${ }^{16}$ For the same reason, inventors have incentives to make sure that no unnecessary patents are cited. As a result, the previous patents cited by a new patent should be a good indicator of previous knowledge that was utilized by the inventor.

This paper uses patent citations as evidence of the existing state of technology when the invention was completed. The assumption is that citations indicate a flow of knowledge. Thus,

\footnotetext{
16 "Narrowing the realm" means that the holder of a patent cannot file an infringement suit against someone whose invention infringes on qualities of the patented invention that were also included in patents cited by the
} 
citations to an earlier patent suggest that the patent provided technological opportunity to the new patent. Frequent citations to a patent provide evidence that the knowledge embodied in that invention has been particularly useful to other inventors. ${ }^{17}$

Using the interpretation of patent citations as measuring flows of knowledge, patents that receive many citations from subsequent patents must have provided greater technological opportunity. We would expect the marginal productivity of research to be greater in the years immediately after the productive patent was revealed. However, a simple count of subsequent citations is not enough. Since the raw number of citations to any patent depends on the total number of patents that follow, it is necessary to look at the probability of citation, rather than a pure count of citations. In section B below a model of patent citation behavior developed by Jaffe and his co-authors is used to find annual estimates of the usefulness of patents in each technology field. These estimates, which I denote as productivity parameters, are then used in section IV as a measure of technological opportunity to control for supply-side influences on energy innovation.

\section{B. Estimating the probability of citation}

The goal of this section is to use patent citations as a measure of technological opportunity. To do this, we need to know the frequency at which patents granted in any given year are cited by patents from subsequent years. However, a simple count of subsequent citations is not enough. Since the raw number of citations to any patent depends on the total number of patents that follow, it is necessary to look at the probability of citation, rather than a pure count of

\footnotetext{
invention.

${ }^{17}$ Jaffe, Fogarty, and Banks (1998) examine the relationships between knowledge flows and patent citations. Their research includes interviews with scientists, $R \& D$ directors, and patent attorneys. They find that, at the level of individual patents, not all citations are indicative of knowledge flows. Other concerns, such as strategically including irrelevant patents to satisfy the patent examiner, add much noise to the citation process. However, at more aggregate levels, such as the patents for an organization or firm, they find that patent citations do seem indicative of knowledge flows.
} 
citations.

To do this, cohorts of patents that could potentially cite each other are created. For each technology group, potentially cited patents are sorted by year of grant, and are denoted CTD. In the United States, a patent application is not made public unless the patent is granted. Thus, the year of grant is the year in which the patented innovation entered the public domain. The patents that do the citing are sorted by year of application, so that the results of this section can be used in estimating the induced innovation model that follows. Citing patents are denoted $C T G$. The data are sorted by $C T D, C T G$ cohorts. Separate cohorts are constructed for each technology group, $i$. For example, one cohort might be citations to all solar energy patents granted in 1975 made by solar energy patents applied for in $1980 .{ }^{18}$ Denoting citations as $c$ and the number of patents from each year as $n$, the probability of citation for patents within each cohort is:

$$
p_{i, C T D, C T G}=\frac{c_{i, C T D, C T G}}{n_{C T D} n_{C T G}} .
$$

Our interest is in the likelihood that patents granted in year CTD will be cited by patents in any subsequent year. To find this, we first need to control for other extenuating factors that affect the likelihood of citation. The model used in this paper builds on a model used in Caballero and Jaffe (1993) and Jaffe and Trajtenberg (1995) for this purpose. These authors identify three factors that affect the probability of a patent being cited by subsequent patents. They are:

1) the rate at which newly produced knowledge, as represented by a newly-patented innovation, diffuses through society,

\footnotetext{
${ }^{18}$ Although the data set includes patents applied for since 1970, citations are only available for the patents granted after 1975. Because of the lag between the application and granting of a patent, the average of which is two years, we are able to consider citations to all patents applied for in 1974 or later.
} 
2) the rate at which new innovations become obsolete, as they are replaced by better inventions, and

3) the ways in which citing behavior has changed over time.

In addition, a fourth factor, the size of the technology group, is added for this paper. About half of all patent citations are to patents in the same classification (Jaffe, Henderson, and Trajtenberg, 1993). However, the technology groups used in this paper range from groups with one or two subclassifications to groups with patent from many different broad classifications. Technology groups with broad definitions are more likely to include subclasses that are not strongly related. As a result, citations to other patents in the group are less likely in these groups.

The reasons for considering the decay and diffusion of knowledge are straightforward. Changes in citing behavior over time must be accounted for because of institutional changes at the patent office that make patents more likely to cite earlier patents than was previously true, even if all other factors are equal. In particular, two changes have played an important role. First, computerization of patent office records has made it easier for both patent examiners and inventors to locate other patents similar to the current invention. Second, increasing legal pressure has made it more important for examiners to be sure that all relevant patents are cited.

Jaffe and his co-authors develop a model that estimates the probability of a patent granted in a given year being cited by future patents, taking into account the three factors mentioned above. This paper extends their model by adding the parameter to control for technology group size. I estimate the probability of citation among patents in a cohort, $p$, as a function of several factors:

- the usefulness of the knowledge represented in the patent being cited $\left(\alpha_{i, C T D}\right)$, 
- the frequency by which patents applied for in the citing year cite earlier patents $\left(\alpha_{C T G}\right)^{19}$,

- the frequency of citations within each technology group $\left(\gamma_{i}\right)$,

- the rate at which the knowledge represented by the cited patent becomes obsolete $\left(\beta_{1}\right)$,

- the rate at which this knowledge diffuses through society $\left(\beta_{2}\right)$.

Note that the first parameter, $\alpha_{i, \text { CTD }}$ is the value of interest for this paper. It is $\alpha_{i, C T D}$ that tells us the likelihood that patents from year CTD will be cited by subsequent patents. The other parameters control for other facets of the patenting process that might affect the likelihood of citation. Higher values of $\alpha_{i, C T D}$ indicate that the patents in question are more likely to be cited by subsequent patents. This implies that the knowledge embodied in those patents is particularly useful. The expected returns on $R \& D$ to researchers building on the knowledge in these patents should be larger than for patents from other years. Thus, lagged values of $\alpha_{i, C T D}$ can be interpreted as a measure of the expected return of $\mathrm{R} \& \mathrm{D}$. I refer to $\alpha_{i, C T D}$ as the productivity parameter.

Figure 3 provides examples of the trends in citation data. The graphs plot the probability of patents granted in year CTD being cited by other patents $x$-years after the year of grant for solar energy and fuel cell patents. Note that only citations to patents in the same technology group are considered. ${ }^{20}$ Each line represents citations to patents granted in a given year. The $\mathrm{x}$-axis measures the lag in years since the patent was granted, and the y-axis shows the probability of a patent from year $C T D$ being cited by a patent $x$-years later. The productivity parameter, $\alpha_{i, C T D}$, can be visualized as the $y$-intercept in the figures. Patents from productive years, such as

\footnotetext{
${ }^{19}$ Since institutional changes will affect all patents equally, this parameter is not indexed by $i$.

${ }^{20}$ Similar results are obtained when citations to all patents are used. These are discussed in Popp (1998).
} 
solar energy patents from 1975, have higher $y$-intercepts. The figure shows that the probability of citation falls over time, suggesting that the decay of knowledge is more influential than the diffusion of knowledge in determining the probability. ${ }^{21}$ Finally, note that the pattern of decay is similar for patents of different vintages, so that productive patents, such as solar energy patents from 1975, remain more likely to be cited than other patents, even after a lag of several years.

Estimation of the values of the productivity parameter, $\alpha_{i, C T D}$, proceeds as follows. As in the work of Jaffe et al., an exponential distribution is used to capture the probability of citation among cohort members. Adding an error term, $\varepsilon_{i, C T D, C T G}$, the probability of citation among cohort members can be written as:

$$
p_{i, C T D, C T G}=\gamma_{i} \alpha_{i, C T D} \alpha_{C T G} \exp \left[-\beta_{1}(C T G-C T D)\right]\left\{1-\exp \left[-\beta_{2}(C T G-C T D)\right]\right\}+\varepsilon_{i, C T D, C T G} .
$$

Equation (3) is estimated using non-linear least squares, using all patents granted from 1970 to 1989 as the cited years, and all patents applied for from 1974 to 1991 as the citing years. ${ }^{22}$ Because some of the technology groups have few patents, and thus few citations, the productivity parameter is only estimated for 12 of the 22 technology fields. To identify the parameters, it is necessary to normalize one of each of the $\alpha^{\text {'s }}$ to be 1 . For $\alpha_{i, C T D}$, patents granted in 1970 are normalized to 1 . Thus, estimates greater than one mean that patents granted in those years were more useful to future inventors than patents from the base year of 1970. Finally, since

\footnotetext{
${ }^{21}$ In these figures, the probability of citation is highest in the year after the patent is granted. This is consistent with the data in Jaffe and Trajtenberg (1995) as well. In their paper, they find that most cites occur in patents granted three years after the initial patent. In this data set, citing patents are sorted by year of application. Since there is, on average, a two year lag between the initial patent application and the granting of the patent, the results are consistent.

${ }^{22}$ The model does not converge when estimating separate $\alpha$ 's for every possible year. Since the main parameters of interest are the productivity parameters, $\alpha_{i, C T D}$, separate coefficients are obtained for each of these. The parameters for institutional changes are grouped by two-year periods. Thus, $\alpha_{1}$ represents citation practices in 1974-1975, $\alpha_{2}$ citation practices in 1976-1977, etc.
} 
this is grouped data, the observations are weighted by $\left(n_{C T D} * n_{C T G}\right)^{0.5}$ to avoid problems with heteroskedasticity (Greene, 1993).

\section{Productivity Estimates}

Figure 4 displays the results of estimation. Note that not all technology groups were included in the regression, because smaller technology groups include very few citations to other patents in the group. For each technology included, a plot of the productivity parameter is presented. Numerical results for the remaining parameters are given after the plots. Readers interested in a more detailed discussion of these other parameters are referred to Popp (1998).

To interpret the plots, recall that the productivity parameters in 1970 were normalized to 1. Estimates greater than one for a given year indicate that patents granted in that year are more likely to be cited by future patents than patents which were granted in 1970, and estimates less than one indicate that those patents are less likely to be cited. A downward trend in the productivity parameter is found for most of the technology groups. Even after controlling for exogenous factors such as the age of patents, newer patents are less likely to be cited than older patents. This suggests that there are diminishing returns to energy research over time.

\section{Results}

Having obtained estimates of the productivity of knowledge in section III, we now move to estimating the induced innovation relationship. Lagged values of the productivity estimates just obtained are used as measures of the marginal productivity of research at time $t$, making it possible to control for supply-side factors that affect the level of innovation, as well as demandside factors such as energy prices. The equation to estimate is: 


$$
\begin{array}{r}
\log \left(\frac{E P A T_{i, t}}{\text { TOTPAT }_{t}}\right)=\mu_{i}+\lambda_{i} \log P_{E, t}+\rho \log P_{E, t-1}+\theta_{i} \log \alpha_{i, t-1}+\eta_{\mathbf{i}} \log \mathbf{Z}+\varepsilon_{i t} \\
i=1, \ldots, 17 ; t=1, \ldots, 20
\end{array}
$$

Technology groups that contain few patents are grouped together, resulting in 17 different technology groups included in the estimation. ${ }^{23}$ A time trend is used to control for the returns to R\&D in technology groups that were too small to obtain a productivity parameter in section III. If the returns to research are diminishing over time, the coefficient on the time trend will be negative.

Two sets of regressions are completed. The first set of regressions pools the technology groups together to obtain single estimates for each parameter. Within this set, two separate regressions are run pooling all of the supply technologies and all of the demand technologies, respectively, while a third regression pools all the technologies together. Because some of the error in each equation is correlated across technology groups, feasible generalized least squares (FGLS) estimation is used. ${ }^{24}$ The second set of regressions obtains separate results for each technology group, using seemingly unrelated least squares estimation (Zellner 1962). Both sets of regressions are corrected for autocorrelation using the Prais-Winsten transformation.

Table 3 contains the results from the pooled regressions, Table 4 contains the seemingly

\footnotetext{
${ }^{23}$ Two groups of miscellaneous patents were created: Other Supply Technologies, which contains the use of waste gases as fuel, Ocean Thermal Energy Conversion (OTEC), and other uses of natural heat, and Other Demand Technologies, which contains carbothermic processing of aluminum, the use of black liquor in paper manufacturing, insulated windows, and compact fluorescent lightbulbs.

${ }^{24}$ For example, using current and future energy prices is an imperfect substitute for expectations of future prices. Error due to differing expectations (e.g. higher expected prices in 1979 than 1984, although current prices are nearly the same in each year) would affect all the technology groups. In contrast, randomness in the R\&D process will affect each technology differently.
} 
unrelated least squares regressions results, and Table 5 summarizes the results of the seemingly unrelated least squares regressions. T-stats for each coefficient are included in the tables. Almost all the parameters are highly significant. Detailed interpretation of the results is presented below.

\section{A. The Effect of Energy Prices on Innovation}

The results of greatest interest are the effect of energy prices on innovative activity. As Table 3 shows, energy prices play an important role in determining the level of energy innovation. The elasticity of energy patents with respect to current energy prices is 0.125 , and with respect to lagged energy prices is 0.462 . That patenting activity responds so quickly to prices may seem surprising. However, recall that successful patent applications are used as the dependent variable. Because of the lags between filing an application and the granting of the patent, and because the costs of applying are low, patent applications occur early in the inventive process.

Dividing patents into separate groups for supply and demand technologies yields more interesting results. The effect of current energy prices is stronger for supply technologies (1.080) than for demand technologies (0.801). However, what is most interesting is that the elasticity with respect to lagged energy prices is negative for the supply technologies. Why might the results differ between the supply and demand technologies? Most likely, these differences are due to the maturity of the technologies. Most of the demand technologies are well-established technologies that were in use both before and after the energy crisis. In contrast, many of the supply technologies were being introduced for the first time. The know-how for many of these technologies may have existed before the energy crisis, but bringing them to market would not have been feasible until energy prices were high. Thus, some of the new patented innovations may simply have been taken "off the shelf" and brought to market when the conditions were right. The seemingly unrelated regression results, which provide separate coefficients for each technology, 
support this conclusion, as the elasticity of patents with respect to price is particularly high for newer technologies, such as the renewable energy sources. These results suggest that part of the first wave of innovation after the energy crisis was not due to new ideas being discovered, but rather the introduction of these existing technologically feasible ideas to the marketplace.

\section{B. The Returns to $R \& D$}

The regression results show that not only do prices play an important role in inducing new energy innovations, but that the marginal productivity of $R \& D$ is also an important factor. This is shown by the coefficients on the lagged productivity parameters. The signs are positive and significant in the pooled regressions. In addition, the coefficients on the productivity parameter are positive for all but three technologies in the seemingly unrelated regressions. ${ }^{25}$

To interpret the size of the effect of the usefulness of existing knowledge, we need to consider the range of the productivity estimates in section III. The elasticity of patents with respect to the lagged productivity estimates is 0.259 . Thus, a one-percent change in the productivity estimates leads to approximately a one-quarter percent change in patents. Although this may seem small, consider that the range of the productivity estimates is quite large. The average change in productivity estimates from year to year is 26 percent. ${ }^{26}$ As a result, changes in the productivity of research would change patenting activity in an average year by 6.8 percent.

\footnotetext{
${ }^{25}$ A possible explanation for the negative sign in two of the three technologies - coal liquefaction and coal gasification - is presented in section IVC.

${ }^{26}$ This figure uses the absolute value of changes from year to year.
} 
For comparison, the average change in energy prices is only 5.78 percent. Multiplied by the sum of the price elasticities (0.587), we find that the average change in patenting activity due to a change in prices is about 3.4 percent. Even during the peak of the energy crisis, the average change in energy prices was only an 8.8 percent increase, leading to a 5.2 percent increase in patents. ${ }^{27}$ Thus, changes in the marginal productivity of research play an important role in explaining patenting activity in any given year.

Furthermore, the positive coefficients on the productivity parameters suggest that diminishing returns to $\mathrm{R} \& \mathrm{D}$ are an important factor when looking at the research opportunities for a given technology. The productivity estimates have a positive effect on innovation, and most of the productivity estimates reveal diminishing returns over time, as shown in section III. The negative coefficients on the time trend, used in the groups for which productivity estimates were unavailable, reinforce the evidence of diminishing returns over time.

The finding of diminishing returns to research is important to apply the results of this paper to dynamic models of environmental policy. The price elasticities found above suggest that the reaction of the research community to a change in policy, such as a carbon tax, will be swift. Higher prices will quickly lead to a shift towards environmentally-friendly innovation. However, since there are diminishing returns to research in a given field, firms will shift their research towards more productive areas of study as the marginal productivity of such research declines. The burst of patenting activity resulting from a policy change is likely to be short-lived.

These results also present evidence that diminishing returns are a factor in the falling patent/R\&D ratio. If exogenous factors, such as the propensity to patent, were the only culprit,

\footnotetext{
${ }^{27}$ This figure uses the percent change in energy prices in the years 1974 to 1980 , which are the years used in the patent citation analysis.
} 
there should have been no correlation between the productivity estimates and energy $R \& D$ activity, since exogenous factors were removed from the regression by using a percentage of patent applications. ${ }^{28}$ Also, note that many of the productivity estimates show an upswing near the end of the 1980's. This support the recent results by Kortum and Lerner (1997), who argue that increasingly fertile technology caused a recent surge in patenting in the United States.

Having shown that the marginal productivity of research helps to explain the level of innovative activity, the next task is to investigate the effects of omitting the productivity of research from the regressions. As Figure 2 shows, patenting activity in the energy fields increase quickly when energy prices rise, but begin to fall before energy prices fall. The positive coefficients on the productivity estimates, as well as the negative coefficient on the time trend, suggest that diminishing returns to research contribute to the quick fall in energy patenting activity. Omitting these controls for the productivity of research should lead to lower estimates of the effect of prices on patenting activity.

This is shown in Table 6A, which omits both the productivity estimates and the time trend from the pooled regressions. Note that the effect of energy prices falls, especially for the demand technologies. In the regression including all technologies, current energy prices appear more important, but this change is more than offset by a negative coefficient on lagged energy prices. Also, omitting controls for the productivity of research changes the sign on government R\&D spending from positive to negative. In each regression, an F-test rejects the null hypothesis that the coefficients of the productivity estimates and time equal zero.

Finally, we ask whether using patent citations to obtain estimates of the marginal productivity of knowledge is necessary, or whether the returns to research can be adequately

28 This result is examined more thoroughly in Popp (1998). 
captured by a time trend. Note that the productivity estimates do not fall monotonically over time. In some technology groups, such as fuel cells and continuous casting, the productivity of research peaked around 1980. In general, these are groups in which there was heavy patenting activity before the sample period, during the 1960's. Diminishing returns led to a low marginal productivity of R\&D during the 1970 's, until new discoveries came along to once again make research in these fields promising.

Table $6 \mathrm{~B}$ provides the results of pooled regressions in which the productivity estimates from section III are replaced by a time trend, so that a time trend is used for all of the technology fields. The results show the value of including the patent citation data. The adjusted R-squares of all three regressions are much lower than the original regressions. Once again, the coefficient on lagged energy prices becomes negative in the overall regression. More astonishingly, in the demand technologies, both price coefficients become negative! The effects of government R\&D are also diminished by using a time trend exclusively. Since the productivity of knowledge does not monotonically fall over time, using the patent citation data does provide valuable information.

\section{Federal Energy $R \& D$ Spending}

Since 1973, the U.S. government, through the Department of Energy (DOE), has spent over 50 billion dollars on energy-related $\mathrm{R} \& \mathrm{D}$. Much of this spending was during the energy crises of the 1970's, and included large research projects such as the synfuels program aimed at creating synthetic fuels from coal to substitute for imported fossil fuels. After President Reagan was elected in 1980, government funding for energy research was cut significantly. DOE support for research was limited to long-term, high-risk projects. Federal funding aimed at accelerating the development of new marketable technologies was eliminated. (Cohen and Noll, 1991) Since then, the DOE has focused its efforts on the early stages of research and development - basic research 
to promote general knowledge, and the early stages of applied $\mathrm{R} \& \mathrm{D}$, designed to test the feasibility of new ideas. It is expected that private firms will continue the R\&D process by developing commercially acceptable products. (U.S. Department of Energy, 1987)

Because of these changes in policy, it is not clear a priori what the expected sign of the federal R\&D coefficients would be. With a focus on basic knowledge, DOE research may not lead to the production of much patentable knowledge, but it is likely to be the foundation for more R\&D by private firms. If this goal is met, federal $R \& D$ spending should compliment private research. However, in the case of research aimed at accelerating new products to the market, federal $\mathrm{R} \& \mathrm{D}$ could be a compliment - for example, if firms are included as contractors in large government projects. Conversely, federal research projects may merely crowd out the research efforts of private firms, making federal $R \& D$ a substitute for private $R \& D$.

Although the changes in federal research policy make identifying the effects of research difficult, some broad insights can be gleamed from the regression results. In general, we find that government R\&D has little effect on private patenting activity. Only for the supply technologies do both current and lagged government $R \& D$ have a positive effect. Since much of the government's R\&D efforts during the 1970's were aimed at energy supply, this suggests that the large-scale research effort undertaken at the time did have at least limited success. However, the magnitude of the elasticities is quite small, suggesting that the effect was minimal. The sum of the elasticities for current and lagged government $R \& D$ for the supply technologies is only 0.265 . To put this in perspective, consider that the private cost of $\mathrm{R} \& \mathrm{D}$ is about $\$ 1$ million. ${ }^{29}$ In contrast, federal R\&D spending must increase by over $\$ 100$ million to induce a new patent!

${ }^{29}$ That is, there are about $\$ 1$ million of private R\&D expenditures per patent granted in the U.S. 
As an example of the effectiveness of government $R \& D$, consider the effects of federal research on coal gasification patents. Coal gasification was part of the synfuels program that was expanded greatly during the energy crisis, but with little success. Although this research did lead to an increase in the number of patents, the synfuels program soon ended without success. Note from Figure 4 that the productivity estimates for the coal gasification were low during this period. It is unlikely that much private research would have been done on these technologies without government support. These results suggest that one reason for the failure of the synfuels program was that more and more money was being pumped into a technology with limited prospects for success. $^{30}$

In general, the regression results appear to indicate that federal research spending is not a productive means of increasing energy $R \& D$. The technologies for which federal $R \& D$ has a large effect were also technologies with a low marginal productivity of R\&D. In other cases, market forces such as higher prices seem to offer enough incentive to perform research. Policymakers interested in encouraging the development of new, environmentally-friendly technologies would be advised to focus their efforts on making such technologies more feasible, such as by introducing a carbon tax or pollution permits, rather than simply increasing funding on government-sponsored research.

\section{Conclusions}

This paper uses patent data to study the impact of energy prices on energy-saving technology. It adds to the literature on induced innovation by looking not only at the effects of prices on technological change, but also at the effects of the usefulness of existing knowledge on technological change. The key findings of this paper are:

\footnotetext{
${ }^{30}$ For a more detailed account of the federal research effort into synthetic fuels, see Cohen and Noll (1991).
} 
- Energy prices have a strong positive impact on new innovations in the 17 energy technology fields studied.

- The reaction to energy prices is quick, especially for energy supply technologies.

- The expected value of research also plays an important role in determining the level of innovative activity.

- Since the expected value of research falls over time, this is evidence of diminishing returns to research over time.

- Government policies aimed at innovation, such as government-funded R\&D, have had little effect on private innovation.

The results of this paper should be of interest to a wide audience. For energy and environmental economists, the most significant result of this paper is the strong, positive impact of energy prices on new innovations. This suggests that environmental taxes and regulations not only reduce pollution by changing behavior away from polluting activities, but also by encouraging the development of new technologies that make achieving pollution control goals less costly in the long-run. However, it also makes clear that simply relying on technological change as a panacea for environmental problems is not enough. There must be some mechanism in place that encourages the $R \& D$ to occur.

The results of this paper are also of interest to any economists interested in the determinants of technological change. By using patent citations as a measure of the knowledge available to inventors when they undergo research, this paper confirms that the supply of existing ideas, as well as the demand for new ideas, plays an important role in shaping the direction of R\&D. Technologies for which little chance of successful innovation was possible did not experience significant shocks to innovation when energy prices were higher. In addition, the 
productivity estimates exhibit a downward trend, suggesting diminishing returns to energy research over time.

Finally, one caveat to interpreting the result of diminishing returns to $R \& D$ is necessary. This paper focused on returns to a narrowly defined group of technologies. However, one should not jump to the broad conclusion that returns to $R \& D$ must be falling across all technologies. Indeed, we find that the expected return to R\&D is a significant determinant of the amount of R\&D performed in any given period. As the expected success rate of energy R\&D falls, investment shifts out of energy $R \& D$, presumably to fields with a greater chance for success. Since research is shifting out of fields with diminishing returns, the diminishing returns in these fields cannot be solely responsible for the falling patent-to-R\&D ratio in the U.S. economy as a whole. Only if the fields which research efforts are shifted towards are less productive is the falling patent-to-R\&D ratio explained only by diminishing returns. However, it may be possible that enough productive new areas of research appear each period to keep the overall returns to R\&D high. If this is the case, diminishing returns would not explain the overall fall in the patentto-R\&D ratio. Studies such as this one, applied to other technological fields, could help to shed some light on this question. 


\section{APPENDIX A - ADDITIONAL DATA USED IN REGRESSIONS}

\section{A. Energy Prices}

Data on prices are taken from the State Energy Price and Expenditure Report, published by the Energy Information Administration. Prices are in constant 1987 dollars, deflated by a GNP fixed-weight price deflator. Prices are available for different sectors of the economy, such as industrial and residential, and by type of fuel, such as coal or fossil fuels. In addition, an index of total energy prices is provided. The index provides the cost of all energy sources consumed, in 1987 dollars per million British thermal unit (Btu). Figure 5 shows the trends in these prices since 1970. When estimating the effects of energy prices on innovation in section IV, different energy prices are used as the dependent variable for different technologies, depending on the nature of the technology. For example, since coal gasification and coal liquefaction are intended to be substitutes for traditional fossil fuels, the price of fossil fuels is used for these equations. For the production of aluminum, an electricity-intensive procedure, electricity prices are used. A general index of industrial energy prices is used for the technologies relating to the recovery of waste heat. The energy price used as the dependent variable for each equation will be presented in the footnote to tables presenting regression results.

\section{B. Federal R\&D Funding}

Data for government R\&D are taken from Public Citizen (1992). As with the energy price data, various $R \& D$ expenditures are used for the different technologies. A sharp drop in funding for alternative energy sources and conservation occurs after Ronald Reagan became President in 1981. Since government R\&D targets the early stages of the inventive process, it may take several years for firms to take advantage of that knowledge and develop a patentable invention. Thus, lagged values of government $R \& D$ are included in the regression. 


\section{Technology-specific variables}

In addition to the aforementioned data, several technology-specific variables are also used. These variables capture the effects of characteristics unique to the individual technology groups, and help to explain some of the unique trends in the data described in footnote 11. For continuous casting, the data set includes the price of ore purchased by steel producers. Continuous casting makes more efficient use of raw materials, so its use becomes more attractive as the cost of these materials increases. We would expect a positive relationship between the price of ore and continuous casting patents. For fuel cells, the excess capacity of electric utilities is included. In addition to using fossil fuels more efficiently, fuel cells also offer the advantage of modularity. Individual cells are small, and can be linked to generate as much power as needed. They can be installed in small spaces, and little lead-time is needed to set up a plant that uses fuel cells to generate electricity. Having over-estimated future electricity demand in the 1970's, the industry built too many new, large power plants. In this climate, fuel cells offered a more flexible alternative when increased power-generating capacity was needed in the 1980's. (OTA, 1991b) We would expect a positive correlation between excess capacity and fuel cell patents.

For the use of waste products as energy, the price of waste to the utilities is included in the data set. Note from Figure 2 that waste fuel patents increase during the 1980's. During this period, available space in landfills was decreasing. Incineration of trash was seen as an attractive disposal alternative. The price of waste products to utilities fell over this period, as the supply curve for waste had shifted out. The use of the price of waste will capture this effect. A negative correlation between the price of waste and the invention of waste fuel patents is expected. 


\section{APPENDIX B - ENERGY TECHNOLOGY GROUPS STUDIED}

For this paper, 22 groups of energy-related patents were created, with each group representing a different technology. Of these, 11 are related to energy supply, and 11 are related to energy demand. Groups were included based on their importance to energy conservation and the clarity of patent classification. Importance to energy conservation was determined by a review of literature on energy conservation, including references on industrial energy conservation and several Department of Energy publications. Clarity of patent classification means that the patent classifications included must clearly be used for energy conservation purposes. ${ }^{31}$ Appendix $\mathrm{C}$ lists the patent classifications in each of the 22 technology groups.

Supply technologies included in the data set were those that are substitutes for fossil fuels. Nuclear technologies were not included, since nuclear patents would be strongly influenced by changing attitudes about the safety of nuclear power and the resulting changes in the regulatory burden of the nuclear industry. Technologies that were utilized include technologies for getting fuel from coal, fuel cells, and renewable sources such as solar, wind, geothermal and biomass energy.

Demand technologies focus mainly on industrial energy consumption. They include a mixture of technologies chosen for specific industries, and technologies with a more general usage. Energy use varies greatly across sectors. Petroleum refining, chemicals, primary metals, pulp and paper, food, and ceramics and glass accounted for $74 \%$ of total industrial energy use in 1988. In some cases, energy use is high because the output of the industry is high - food and oil

\footnotetext{
${ }^{31}$ For example, refrigeration is energy-intensive activity that could be improved by R\&D. Such R\&D might focus on more efficient compressors or better insulation materials. However, patents in the refrigeration subclass are organized by the end-use of refrigeration, rather than by the components of refrigerators. Since there are other reasons for inventive activity in refrigerators, such as to reduce CFC emissions, refrigeration patents are not used.
} 
and gas extraction are examples. In other industries, both output and the energy intensity is high. Such industries are petroleum refining, steel, organic chemicals, and paper (OTA, 1993). Table B1 presents energy consumption and energy intensity in selected industries. Energy intensity is calculated as real energy expenditures divided by real value added in the industry. Most energy $R \& D$ is concentrated in these energy intensive industries.

Table B1 - Energy Use for Selected Industries

\begin{tabular}{|c|c|c|c|c|c|c|c|}
\hline \multirow[b]{2}{*}{ Industry } & \multirow[b]{2}{*}{ SIC } & \multicolumn{3}{|c|}{$\begin{array}{l}\text { Real Energy Consumption } \\
\text { (millions of } 1987 \text { \$s) }\end{array}$} & \multicolumn{3}{|c|}{$\begin{array}{c}\text { Energy Intensity } \\
\text { (Real Energy/Real Value } \\
\text { Added) }\end{array}$} \\
\hline & & 1971 & 1981 & 1991 & 1971 & 1981 & 1991 \\
\hline Food & 20 & 3,916 & 4,534 & 4,597 & 0.05 & 0.05 & 0.03 \\
\hline Paper & 26 & 4,289 & 4,970 & 5,184 & 0.13 & 0.13 & 0.10 \\
\hline Chemicals & 28 & 8,028 & 10,389 & 8,174 & 0.10 & .012 & 0.06 \\
\hline Petroleum Refining & 29 & 3,836 & 4,214 & 4,176 & 0.17 & 0.26 & 0.18 \\
\hline Stone, Clay, and Glass & 32 & 3,932 & 4,027 & 3,194 & 0.13 & 0.14 & 0.10 \\
\hline Primary Metals & 33 & 10,225 & 10,765 & 7,008 & 0.18 & 0.21 & 0.17 \\
\hline Steel & 3312 & 6,064 & 5,741 & 2,951 & 0.22 & 0.27 & 0.21 \\
\hline Aluminum & 3334 & 1,101 & 1,539 & 1,266 & 0.53 & 0.65 & 0.70 \\
\hline
\end{tabular}

Source: Calculated from data in the NBER Manufacturing Productivity Database

Of the demand-side technology groups, some have general industrial applications. Industrial processes produce much heat that is never used. Recovery of this waste heat would allow for substantial energy savings. Three of the categories relate to the use of waste heat waste heat, heat exchange, and heat pumps. Some of the technology groups chosen relate to specific energy intensive industries. For example, continuous casting is a method of steel production that requires less energy than traditional techniques. Two means of processing aluminum, the traditional electrolytic process and a newer procedure, carbothermic processing, 
are included. Black liquor technology is the use of waste products in the manufacture of paper. Industry-specific technologies could not be chosen for all of the energy intensive industries, because in some of these industries there are a broad range of energy uses, making it difficult to focus on individual technologies. For example, the chemical industry makes a diverse range of products such as rubber, plastics, soaps, paints, industrial gases, fertilizers, and pharmaceuticals. Obviously, different technologies to conserve energy would be needed in the production of these various products. In addition, for products such as these, it is difficult to identify innovations that are clearly related to energy conservation, as opposed to other improvements in the product. 


\section{APPENDIX C: U.S. patent classifications related to energy}

Guide to definitions: The first phrase is the main classification. For example, class 208 contains patents for Mineral Oils: Processes and Products. These are followed by the various subclassifications, listed in descending order of precedence.

\section{Supply Technologies:}

Coal Liquefaction: 208/400-435

\section{Coal Gasification:}

$48 / 200$

$48 / 201$

$48 / 202$

$48 / 210$

$48 / 71$

$48 / 72$

$48 / 73$

$48 / 77$

$48 / 98$

$48 / 99$

$48 / 100$

$48 / 101$

Solar Energy:

60/641.8-641.15

$62 / 235.1$

126/561-568

126/569-713

$126 / 903$

$126 / 904$

$126 / 905$

126/906

$126 / 910$
Mineral Oils: Processes and Products/By treatment of solid material (e.g. coal liquefaction)

Gas: Heating and Illuminating/Processes/Coal, oil and water

Gas: Heating and Illuminating/Processes/Coal and oil

Gas: Heating and Illuminating/Processes/Coal and water

Gas: Heating and Illuminating/Processes/Coal

Gas: Heating and Illuminating/Generators/Cupola/Coal, oil and water

Gas: Heating and Illuminating/Generators/Cupola/Coal and oil

Gas: Heating and Illuminating/Generators/Cupola/Coal and water

Gas: Heating and Illuminating/Generators/Cupola/Producers/Coal

Gas: Heating and Illuminating/Generators/Retort/Coal, oil and water

Gas: Heating and Illuminating/Generators/Retort/Coal and water

Gas: Heating and Illuminating/Generators/Retort/Coal and oil

Gas: Heating and Illuminating/Generators/Retort/Coal

Power Plants/Utilizing natural heat/Solar

Refrigeration/Utilizing solar energy

Stoves and Furnaces/Solar heat collector for pond or pool

Stoves and Furnaces/Solar heat collector

Stoves and Furnaces/Cross-Reference Art/Solar collector cleaning device

Stoves and Furnaces/Cross-Reference Art/Arrangements for sealing solar collector

Stoves and Furnaces/Cross-Reference Art/Preventing condensing of moisture in solar collector

Stoves and Furnaces/Cross-Reference Art/Connecting plural solar collectors in a circuit

Stoves and Furnaces/Cross-Reference Art/Heat storage liquid

Solar Energy - Batteries:

$136 / 206$

$136 / 243$

$136 / 244-251$

$136 / 252-265$
Batteries: Thermoelectric and Photoelectric/Thermoelectric/Electric power generator/ Solar energy type

Batteries: Thermoelectric and Photoelectric/Photoelectric

Batteries: Thermoelectric and Photoelectric/Photoelectric/Panel

Batteries: Thermoelectric and Photoelectric/Photoelectric/Cells 
Fuel Cells:

429/12-46

Chemistry: Electrical Current Producing Apparatus, Product, and Process/Fuel cell, subcombination thereof or method of operating

Wind:

$290 / 44$

$290 / 55$

$416 / 132 B$

Prime-Mover Dynamo Plants/Electric control/Fluid-current motors/Wind Prime-Mover Dynamo Plants/Fluid-current motors/Wind

Fluid Reaction Surfaces (i.e., Impellers)/Articulated resiliently mounted or self-shifting impeller or working member/Sectional, staged or non-rigid working member/windmills

416/196A Fluid Reaction Surfaces (i.e., Impellers)/Lashing between working members or external bracing/Connecting adjacent work surfaces/Non-turbo machine (windmills)

416/197A Fluid Reaction Surfaces (i.e., Impellers)/Cupped reaction surface normal to rotation plane/Air and water motors (natural fluid currents)

Geothermal energy:

$60 / 641.2-641.5$

Power Plants/Utilizing Natural Heat/Geothermal

Using waste as fuel:

$110 / 235-259$

Furnaces/Refuse incinerator

$110 / 346$

Furnaces/Incinerating refuse

Using waste gases as fuel:

431/5 Combustion/Process of combustion or burner operation/Burning waste gas, e.g. furnace gas, etc.

Ocean Thermal Energy Conversion (OTEC):

60/641.7 Power Plants/Utilizing natural heat/Ocean Thermal Energy Conversion (OTEC)

Renewable Energy - General:

$60 / 641.1$

Power Plants/Utilizing natural heat

$60 / 641.6$

Power Plants/Utilizing natural heat/With natural temperature differential 
Demand Technologies:

Waste heat:

122/7R Liquid Heaters and Vaporizers/Industrial/Waste heat

7A Liquid Heaters and Vaporizers/Industrial/Waste heat/Steel converter

7B Liquid Heaters and Vaporizers/Industrial/Waste heat/Additional burner

7C Liquid Heaters and Vaporizers/Industrial/Waste heat/Waste sulfate

7D Liquid Heaters and Vaporizers/Industrial/Waste heat/Carbon monoxide

60/597-624 Power Plants/Fluid motor means driven by waste heat or by exhaust energy from internal combustion engine

Heat exchange - Refrigeration:

62/4 Refrigeration/Intermediate fluid container transferring heat to heat absorber or holdover/Flow line connected transfer fluid supply and heat exchanger

62/79 Refrigeration/Processes/Exchanging heat between plural systems, e.g., disparate

62/513 Refrigeration/Refrigeration producer/ Heat exchange between diverse function elements

62/515-528 Refrigeration/Refrigeration producer/Evaporator, e.g.,. heat exchanger

Heat exchange-general:

165

Heat Exchange

Heat pumps:

$62 / 238.7$

$62 / 324.1-325$

Stirling engine:

$60 / 517-526$

Continuous casting:

$148 / 541$

$148 / 551$

$164 / 263$
Refrigeration/Disparate apparatus utilized as heat source or absorber/With vapor compression system/Reversible, i.e. heat pump

Refrigeration/Reversible, i.e., heat pump

Power Plants/Motor operated by expansion and/or contraction of a unit of mass of motivating medium/Unit of mass is a gas which is heated or cooled in one of a plurality of constantly communicating expansible chambers and freely transferable therebetween

Metal Treatment/Process of modifying of maintaining internal physical structure (i.e. microstructure) or chemical properties of metal, process of reactive coating of metal and process of chemical-heat removing (e.g., flame-cutting, etc.) or burning of metal/With casting or solidifying from melt/Iron(Fe) or iron base alloy/Continuous casting

Metal Treatment/Process of modifying of maintaining internal physical structure (i.e. microstructure) or chemical properties of metal, process of reactive coating of metal and process of chemical-heat removing (e.g., flame-cutting, etc.) or burning of metal/With casting or solidifying from melt/Aluminum (Al) or aluminum base alloy/Continuous casting Metal Founding/With product severing or trimming means/Associated with continuous casting means 
$164 / 268$

$164 / 415$

$164 / 416$

$164 / 417$

$164 / 418-444$

$164 / 445-446$

$164 / 447-448$

$164 / 449.1-450.5$

$164 / 451-455$

$164 / 459-491$

$164 / 502-504$

$164 / 505-509$

$164 / 154.4$

$164 / 154.5$
Metal Founding/With coating means/associated with a continuous or semicontinuous casting means

Metal Founding/Means providing inert or reducing atmosphere/In continuous casting apparatus

Metal Founding/Including vibrator means/In continuous casting mold Metal Founding/Combined/Including continuous casting apparatus Metal Founding/Means to shape metallic material/Continuous or semicontinuous casting Metal Founding/Starter bar Metal Founding/Product supporting or withdrawal means for continuous casting apparatus

Metal Founding/Control means responsive to or actuated by means sensing or measuring a condition or variable (i.e., automatic control)/Control of feed material enroute to shaping area/Responsive to material level/In continuous casting apparatus

Metal Founding/Process/With measuring, testing, inspecting, or condition determination/Of continuous or semicontinuous casting

Metal Founding/Process/Shaping liquid metal against a forming surface/Continuous or semicontinuous casting

Metal Founding/Including means to directly apply magnetic force to work or to manipulate or hold shaping means/In continuous casting apparatus

Metal Founding/Means to directly apply electrical or wave energy to work/In continuous casting apparatus

Metal Founding/Control means responsive to or actuated by means sensing or measuring a condition or variable (i.e., automatic control)/Responsive to position or spatial dimension/Responsive to rate of change/Continuous casting

Metal Founding/Control means responsive to or actuated by means sensing or measuring a condition or variable (i.e., automatic control)/Responsive to position or spatial dimension/Continuous casting

Manufacture of aluminum - carbothermic:

$75 / 10.27$

Specialized Metallurgical Processes, Compositions for Use Therein, Consolidated Metal Powder Compositions, and Loose Metal Particulate Mixtures/Processes/Electrothermic processes (e.g., microwave, induction, resistance, electric arc, plasma, etc.)/Carbothermic reduction of Aluminum (Al) compound

Manufacture of aluminum - electrolysis:

$204 / 67$

Chemistry: Electrical and Wave Energy/Processes and

Products/Electrolysis/Synthesis/From fused bath/Metals/Aluminum 
Use of black liquor in paper manufacturing

$162 / 31$

Paper Making and Fiber Liberation/Processes of chemical liberation, recovery or purification of natural cellulose of fibrous material/With regeneration, reclamation, reuse, recycling or destruction of digestion fluid/Flames combustion

$162 / 47$

Paper Making and Fiber Liberation/Processes of chemical liberation, recovery or purification of natural cellulose of fibrous material/With heat recovery

Insulated windows:

$52 / 172$

Static Structures (e.g., Buildings)/Transparent panel; e.g., window, with treatment means/Hygroscopic material; e.g., internal drier

$52 / 776$

$52 / 788$ Static Structures (e.g., Buildings)/Window or window sash, sill, mullion, or glazing/Attaching means securing a pane to a sash member or to another pane/Solid three-sized glazing strip

Static Structures (e.g., Buildings)/Composite prefabricated panel comprising: separate mechanical fastener; means for support securement; disparate edging or stiffener which, in a multi-ply panel, extends outwardly of a major or edge face; or spaced sheets with inturned edge-forming flanges/Sandwich or hollow with sheetlike facing members/Parallel, transparent panes, (e.g., double glass window panel, etc.)

$52 / 790$ Static Structures (e.g., Buildings)/Composite prefabricated panel comprising: separate mechanical fastener; means for support securement; disparate edging or stiffener which, in a multi-ply panel, extends outwardly of a major or edge face; or spaced sheets with inturned edge-forming flanges/Sandwich or hollow with sheetlike facing members/Internal spacer

Compact fluorescent lightbulbs:

Note: no classification could be found for these. Patents for compact fluorescent lightbulbs were found by a keyword search on the MicroPatent database. Because this is a relatively new technology, it was not necessary to extend the search before 1975 by using the EPO tapes. 


\section{REFERENCES}

Ahmad, S. (1966), “On the Theory of Induced Innovation,” Economic Journal, 76, 344-357.

Altshuler, Rosanne (1987), "A Dynamic Analysis of the Research and Experimentation Credit," National Tax Journal, 41, 453-466.

Basberg, Bjørn L. (1987), "Patents and the Measurement of Technological Change: A Survey of the Literature," Research Policy, 16, 131-141.

Binswanger, Hans P. (1974), “A Microeconomic Approach to Innovation,” Economic Journal, 84, 940-958.

Binswanger, Hans P. (1978a), “The Microeconomics of Induced Technical Change," in Induced Innovation: Technology, Institutions, and Development, ed. by $\mathrm{H}$. Binswanger and Vernon Ruttan, John Hopkins University Press, Baltimore, MD.

Binswanger, Hans P. (1978b), "Issues in Modeling Induced Technical Change," in Induced Innovation: Technology, Institutions, and Development, ed. by $\mathrm{H}$. Binswanger and Vernon Ruttan, John Hopkins University Press, Baltimore, MD.

Caballero, Ricardo J. and Adam B. Jaffe (1993), "How High are the Giants' Shoulders: An Empirical Assessment of Knowledge Spillovers and Creative Destruction in a Model of Economic Growth," in Olivier J. Blanchard and Stanley Fischer, eds., NBER Macroeconomics Annual 1993, MIT Press, Cambridge, MA.

Chavas, Jean-Paul, Michael Aliber, and Thomas L. Cox (1997), "An Analysis of the Source and Nature of Technical Change: The Case of U.S. Agriculture," Review of Economics and Statistics, 79(3), 482-492.

Cohen, Linda R. and Roger G. Noll (1991), The Technology Pork Barrel, The Brookings Institution, Washington, D.C.

Eisner, Robert, Steven H. Albert, and Martin A. Sullivan (1984), “The New Investment Tax Credit for R\&D: Incentive or Disincentive?", National Tax Journal, 37, 171-183.

Evenson, Robert E. (1991), "Patent Data by Industry," Cowles Discussion Paper no. 620, Yale University.

Evenson, Robert E. and Yoav Kislev (1975), Agricultural Research and Productivity, Yale University Press, New Haven, CT.

Goulder, Lawrence H. and Stephen H. Schneider (forthcoming), "Induced Technological Change and the Attractivenes of $\mathrm{CO}_{2}$ Emissions Abatement," Resource and Energy Economics.

Greene, William H. (1993), Econometric Analysis, Macmillan Publishing Co., New York. 
Griliches, Zvi (1990), "Patent statistics as economic indicators: a survey," Journal of Economic Literature, 28, 1661-1707.

Griliches, Zvi (1989), "Patents: Recent trends and puzzles," Brookings Papers on Economic Activity: Microeconomics, 291-330.

Hall, Bronwyn H. (1992), "R\&D Tax Policy During the Eighties: Success or Failure?”, in Tax Policy and the Economy, vol. 7, James M. Poterba ed., MIT Press, Cambridge, MA.

Hausman, Jerry, Bronwyn H. Hall, and Zvi Griliches (1984), "Econometric Models for Count Data with an Application to the Patents-R \& D Relationship," Econometrica, 52, 909938.

Jaffe, Adam B., Michael S. Fogarty, and Bruce A. Banks (1998), "Evidence from Patents and Patent Citations on the Impact of NASA and Other Federal Labs on Commercial Innovation," Journal of Industrial Economics, 46, 183-205.

Jaffe, Adam B. and Karen Palmer (1997), "Environmental Regulation and Innovation: A Panel Data Study," Review of Economics and Statistics, 79, 610-619.

Jaffe, Adam B. and Manuel Trajtenberg (1995) "Flows of Knowledge From Universities and Federal Labs: Modeling the Flow of Patent Citations Over Time and Across Institutional and Geographic Boundaries,” NBER Working Paper \#5712.

Kamien, Morton I. and Nancy L. Schwartz (1968), "Optimal Induced Technical Change," Econometrica, 36, 1-17.

Kortum, Samuel and Josh Lerner (1997), "Stronger Protection or Technological Revolution: What is Behind the Recent Surge in Patenting?" NBER Working Paper \#6204.

Lanjouw, Jean O. and Ashoka Mody (1996), "Innovation and the International Diffusion of Environmentally Responsive Technology," Research Policy, 25, pp. 549-571.

Levin, Richard C., Alvin K. Klevorick, Richard R. Nelson, and Sidney G. Winter (1987), "Appropriating the Returns from Industrial Research and Development," Brookings Papers on Economic Activity, 3, 783-820.

Manne Alan S. and Richard Richels (1992), Buying Greenhouse Insurance: The Economic Costs of $\mathrm{CO}_{2}$ Emission Limits, MIT Press, Cambridge, MA.

Mansfield, Edwin (1986), “The R\&D Tax Credit and Other Technology Policy Issues," American Economic Review, 76, 190-194.

Mowrey, David C. and Nathan Rosenberg (1979), “The Influence of Market Demand Upon Innovation: A Critical Review of Some Recent Empirical Studies," Research Policy, 8, 103-153. 
NBER Manufacturing Productivity Database, available on-line.

Newell, Richard G., Adam B. Jaffe, and Robert N. Stavins (1998), "The Induced Innovation Hypothesis and Energy-Saving Technological Change," NBER working paper \#6437.

Nordhaus, William (1997), "Modeling Induced Innovation in Climate-Change Policy," paper presented at the 1997 NBER Summer Institute on the Environment.

Nordhaus, William (1994), Managing the Global Commons: The Economics of the Greenhouse Effect, MIT Press, Cambridge, MA.

Nordhaus, William (1973), "Some Skeptical Thoughts on the Theory of Induced Innovation," Quarterly Journal of Economics, 87, 208-219.

Office of Technology Assessment (1993), Industrial Energy Efficiency, Washington, D.C., U.S. Government Printing Office, August.

Office of Technology Assessment (1991a), Changing by Degrees: Steps to Reduce Greenhouse Gases, Washington, D.C., U.S. Government Printing Office, February.

Office of Technology Assessment (1991b), Energy Technology Choices: Shaping Our Future, OTA-E-493, Washington, DC, U.S. Government Printing Office, July.

Pakes, Ariel, and Zvi Griliches (1984), "Patents and R \& D at the Firm Level: A First Look," in $R \& D$, Patents, and Productivity, Z. Griliches, ed., University of Chicago Press, Chicago, IL.

Popp, David (1998), "The Productivity of Energy Research," presented at the 1998 NBER Summer Institute on Productivity.

Popp, David (1997), Induced Innovation, Enegy Prices, and the Environment, PhD Dissertation, Yale University.

Public Citizen (1992), "Renewable Energy Research and Development: An Alternative Budget Proposal for FY 1993-1995."

Rosenberg, Nathan (1994), Exploring the Black Box: Technology, Economics, and History, Cambridge University Press, Cambridge, U.K.

Rosenberg, Nathan (1982), Inside the Black Box: Technology and Economics, Cambridge University Press, Cambridge, U.K.

Schmookler, Jacob (1966), Invention and Economic Growth, Harvard University Press, Cambridge, MA.

Thirtle, Colin G. and Vernon W. Ruttan (1987), The Role of Demand and Supply in the Generation and Diffusion of Technical Change, Harwood Academic Publishers, London. 
U.S. Department of Energy (1987), Energy Conservation: Multi-Year Plan FY 1989-93.

Zellner, A. (1962), "An Efficient Method of Estimating Seemingly Unrelated Regressions Equations and Tests of Aggregation Bias," Journal of the American Statistical Association, 57, 500-509. 
Table 1 -- Summary Patent Data

Privately Held U.S. Patents

Sorted By Year of Application

\begin{tabular}{|c|c|c|c|c|c|c|c|c|c|c|c|}
\hline $\begin{array}{l}\bar{\Phi} \\
\stackrel{\nu}{\Phi}\end{array}$ & 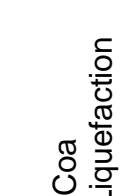 & 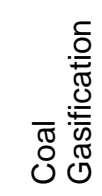 & 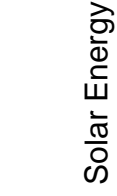 & 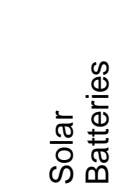 & $\begin{array}{l}\frac{0}{0} \\
\frac{0}{0} \\
\frac{0}{4}\end{array}$ & 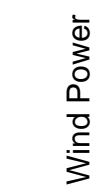 & 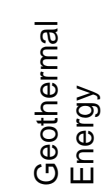 & 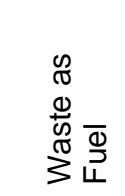 & 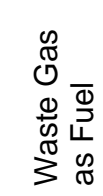 & 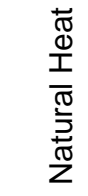 & 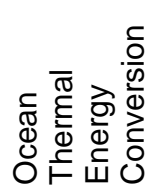 \\
\hline 1970 & $42.0 \overrightarrow{00}$ & 14.00 & 6.00 & 18.00 & 43.00 & 2.00 & 3.00 & 63.00 & 4.00 & 1.00 & 0.00 \\
\hline 1971 & 37.00 & 24.00 & 5.00 & 17.00 & 46.00 & 8.00 & 4.00 & 53.00 & 5.00 & 2.00 & 1.00 \\
\hline 1972 & 27.00 & 16.00 & 10.00 & 13.00 & 33.00 & 7.00 & 5.00 & 52.00 & 12.00 & 0.00 & 0.00 \\
\hline 1973 & 28.00 & 20.00 & 36.00 & 23.00 & 28.00 & 4.00 & 3.00 & 52.00 & 14.00 & 0.00 & 0.00 \\
\hline 1974 & 51.00 & 38.00 & 104.00 & 27.00 & 26.00 & 20.00 & 22.00 & 49.00 & 7.00 & 1.00 & 2.00 \\
\hline 1975 & 45.00 & 31.00 & 218.00 & 63.00 & 38.00 & 37.00 & 17.00 & 29.00 & 13.00 & 7.00 & 3.00 \\
\hline 1976 & 107.00 & 42.00 & 321.00 & 89.00 & 32.00 & 24.00 & 15.00 & 32.00 & 11.00 & 4.00 & 9.00 \\
\hline 1977 & 88.00 & 45.00 & 367.00 & 117.00 & 52.00 & 29.00 & 14.00 & 34.00 & 14.00 & 7.00 & 3.00 \\
\hline 1978 & 114.00 & 53.00 & 333.00 & 142.00 & 42.00 & 39.00 & 15.00 & 41.00 & 6.00 & 5.00 & 7.00 \\
\hline 1979 & 77.00 & 32.00 & 295.00 & 119.00 & 40.00 & 33.00 & 11.00 & 40.00 & 9.00 & 5.00 & 6.00 \\
\hline 1980 & 97.00 & 38.00 & 278.00 & 112.00 & 54.00 & 34.00 & 15.00 & 50.00 & 4.00 & 3.00 & 7.00 \\
\hline 1981 & 100.00 & 27.00 & 208.00 & 119.00 & 54.00 & 37.00 & 14.00 & 44.00 & 3.00 & 1.00 & 3.00 \\
\hline 1982 & 82.00 & 25.00 & 151.00 & 93.00 & 74.00 & 28.00 & 12.00 & 58.00 & 7.00 & 1.00 & 2.00 \\
\hline 1983 & 74.00 & 22.00 & 102.00 & 74.00 & 47.00 & 23.00 & 12.00 & 50.00 & 4.00 & 1.00 & 2.00 \\
\hline 1984 & 70.00 & 15.00 & 104.00 & 86.00 & 39.00 & 13.00 & 2.00 & 44.00 & 4.00 & 1.00 & 1.00 \\
\hline 1985 & 34.00 & 18.00 & 85.01 & 80.01 & 54.01 & 9.00 & 5.00 & 46.01 & 6.00 & 0.00 & 0.00 \\
\hline 1986 & 20.01 & 10.00 & 42.01 & 73.02 & 72.02 & 11.00 & 4.00 & 61.02 & 3.00 & 0.00 & 1.00 \\
\hline 1987 & 12.01 & 16.01 & 35.03 & 54.05 & 65.06 & 9.01 & 6.01 & 83.07 & 8.01 & 0.00 & 2.00 \\
\hline 1988 & 14.03 & 10.02 & 44.09 & 63.13 & 54.11 & 6.01 & 4.01 & 69.14 & 2.00 & 2.00 & 0.00 \\
\hline 1989 & 22.13 & 14.08 & 33.19 & 42.25 & 51.30 & 6.04 & 6.04 & 84.49 & 10.06 & 0.00 & 0.00 \\
\hline 1990 & 16.22 & 9.13 & 26.36 & 40.56 & 59.82 & 6.08 & 4.06 & 102.41 & 5.07 & 2.03 & 1.01 \\
\hline 1991 & 10.38 & 4.15 & 32.17 & 47.73 & 48.77 & 14.53 & 4.15 & 97.55 & 12.45 & 0.00 & 0.00 \\
\hline 1992 & 11.74 & 4.70 & 27.01 & 52.85 & 61.07 & 12.92 & 10.57 & 92.79 & 9.40 & 1.17 & 2.35 \\
\hline 1993 & 8.28 & 1.66 & 23.19 & 19.88 & 57.98 & 9.94 & 1.66 & 59.63 & 16.56 & 0.00 & 0.00 \\
\hline
\end{tabular}

Table shows the number of successful patent applications in each technology field by U.S. inventors.

As discussed in the text, data after 1985 have been scaled up to include applications not yet acted upon by the U.S. Patent Office.

Table continued on next page 
Table 1 -- Summary Patent Data (continued)

Privately Held U.S. Patents

Sorted By Year of Application

\begin{tabular}{|c|c|c|c|c|c|c|c|c|c|c|c|}
\hline$\stackrel{\stackrel{\Phi}{亠 凶}}{>}^{\bar{D}}$ & 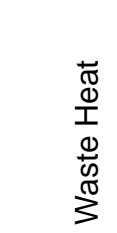 & 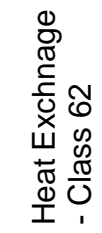 & 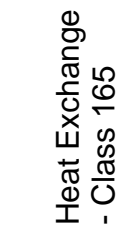 & 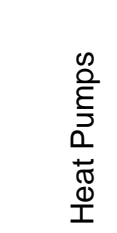 & 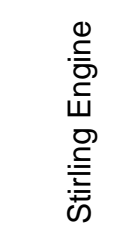 & 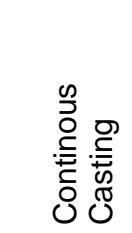 & 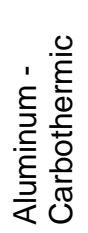 & 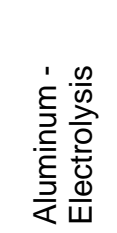 & 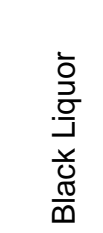 & 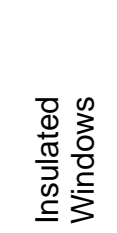 & 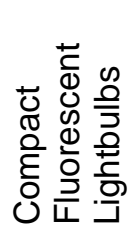 \\
\hline 1970 & 17.00 & 11.00 & 425.00 & 0.00 & 13.00 & 84.00 & 2.00 & 8.00 & 4.00 & 5.00 & 0.00 \\
\hline 1971 & 18.00 & 13.00 & 423.00 & 2.00 & 13.00 & 115.00 & 0.00 & 9.00 & 2.00 & 3.00 & 0.00 \\
\hline 1972 & 21.00 & 11.00 & 340.00 & 8.00 & 12.00 & 67.00 & 1.00 & 10.00 & 3.00 & 8.00 & 0.00 \\
\hline 1973 & 12.00 & 18.00 & 346.00 & 4.00 & 9.00 & 63.00 & 2.00 & 9.00 & 2.00 & 7.00 & 0.00 \\
\hline 1974 & 28.00 & 15.00 & 382.00 & 7.00 & 17.00 & 48.00 & 2.00 & 4.00 & 2.00 & 12.00 & 2.00 \\
\hline 1975 & 26.00 & 20.00 & 418.00 & 8.00 & 11.00 & 46.00 & 2.00 & 2.00 & 3.00 & 17.00 & 0.00 \\
\hline 1976 & 34.00 & 18.00 & 450.00 & 20.00 & 17.00 & 43.00 & 2.00 & 11.00 & 0.00 & 11.00 & 0.00 \\
\hline 1977 & 29.00 & 19.00 & 505.00 & 17.00 & 11.00 & 37.00 & 3.00 & 10.00 & 3.00 & 9.00 & 1.00 \\
\hline 1978 & 16.00 & 22.00 & 479.00 & 32.00 & 12.00 & 40.00 & 0.00 & 8.00 & 3.00 & 9.00 & 7.00 \\
\hline 1979 & 27.00 & 31.00 & 462.00 & 24.00 & 11.00 & 45.00 & 1.00 & 11.00 & 1.00 & 3.00 & 10.00 \\
\hline 1980 & 25.00 & 13.00 & 443.00 & 21.00 & 18.00 & 44.00 & 4.00 & 15.00 & 3.00 & 13.00 & 3.00 \\
\hline 1981 & 23.00 & 22.00 & 382.00 & 30.00 & 21.00 & 43.00 & 1.00 & 12.00 & 1.00 & 8.00 & 4.00 \\
\hline 1982 & 31.00 & 11.00 & 377.00 & 18.00 & 30.00 & 49.00 & 1.00 & 16.00 & 2.00 & 12.00 & 4.00 \\
\hline 1983 & 22.00 & 10.00 & 317.00 & 11.00 & 21.00 & 61.00 & 2.00 & 14.00 & 1.00 & 7.00 & 6.00 \\
\hline 1984 & 24.00 & 9.00 & 338.01 & 8.00 & 19.00 & 62.00 & 2.00 & 12.00 & 2.00 & 6.00 & 9.00 \\
\hline 1985 & 17.00 & 15.00 & 286.04 & 14.00 & 13.00 & 46.01 & 0.00 & 10.00 & 3.00 & 4.00 & 2.00 \\
\hline 1986 & 13.00 & 23.01 & 323.10 & 15.00 & 13.00 & 80.03 & 6.00 & 5.00 & 1.00 & 12.00 & 1.00 \\
\hline 1987 & 13.01 & 17.01 & 297.26 & 11.01 & 19.02 & 39.03 & 0.00 & 6.01 & 0.00 & 11.01 & 5.00 \\
\hline 1988 & 26.05 & 24.05 & 314.64 & 5.01 & 10.02 & 58.12 & 0.00 & 5.01 & 4.01 & 9.02 & 4.01 \\
\hline 1989 & 24.14 & 22.13 & 310.80 & 14.08 & 12.07 & 38.22 & 0.00 & 5.03 & 3.02 & 20.12 & 6.04 \\
\hline 1990 & 24.34 & 27.38 & 336.64 & 18.25 & 18.25 & 33.46 & 0.00 & 5.07 & 2.03 & 18.25 & 3.04 \\
\hline 1991 & 18.68 & 35.28 & 391.22 & 21.79 & 11.41 & 38.40 & 0.00 & 6.23 & 2.08 & 7.26 & 5.19 \\
\hline 1992 & 24.66 & 28.19 & 427.52 & 14.09 & 11.74 & 32.89 & 0.00 & 1.17 & 5.87 & 16.44 & 11.74 \\
\hline 1993 & 21.53 & 13.25 & 349.51 & 16.56 & 4.97 & 31.47 & 1.66 & 3.31 & 1.66 & 1.66 & 6.63 \\
\hline
\end{tabular}

Table shows the number of successful patent applications in each technology field by U.S. inventors.

As discussed in the text, data after 1985 have been scaled up to include applications not yet acted upon by the U.S. Patent Office. 
Table 2 -- Correlations Between Energy Prices and Patent Counts

U.S. Patents

Sorted By Year of Application

\begin{tabular}{l}
\hline Technology \\
\hline Coal Liquefaction \\
Coal Gasification \\
Solar Energy \\
Solar Batteries \\
Fuel Cells \\
Wind Power \\
Geothermal Energy \\
Waste as Fuel \\
Waste Gas as Fuel \\
Natural Heat \\
Ocean Thermal Energy Conversion \\
Waste Heat \\
Heat Exchnage - Class 62 \\
Heat Exchange - Class 165 \\
Heat Pumps \\
Stirling Engine \\
Continous Casting \\
Aluminum - Carbothermic \\
Aluminum - Electrolysis \\
Black Liquor \\
Insulated Windows \\
Compact Fluorescent Lightbulbs \\
\hline \hline
\end{tabular}

\begin{tabular}{rrr}
\multicolumn{3}{c}{ correlation with: } \\
\hline current & prices lagged & prices lagged 2 years \\
prices & 1 year & \\
\hline 0.424 & 0.251 & 0.034 \\
0.059 & -0.179 & -0.299 \\
0.325 & 0.100 & -0.148 \\
0.675 & 0.548 & 0.331 \\
0.517 & 0.611 & 0.645 \\
0.477 & 0.223 & -0.093 \\
0.246 & -0.065 & -0.323 \\
-0.073 & 0.028 & 0.162 \\
-0.413 & -0.544 & -0.567 \\
-0.036 & -0.189 & -0.329 \\
0.233 & 0.008 & -0.153 \\
0.283 & 0.055 & -0.151 \\
-0.030 & -0.110 & -0.177 \\
-0.175 & -0.297 & -0.413 \\
0.544 & 0.373 & 0.120 \\
0.662 & 0.597 & 0.463 \\
-0.442 & -0.209 & 0.142 \\
0.107 & 0.145 & 0.010 \\
0.525 & 0.424 & 0.340 \\
-0.287 & -0.181 & -0.199 \\
0.093 & -0.047 & -0.184 \\
0.548 & 0.394 & 0.412 \\
\hline \hline
\end{tabular}

Table presents correlations between energy prices and the number of patent applications per year. Only privately held patents by American inventors are included. 
Table 3 -- Pooled Regression Results

Dependent variable: percentage of total domestic patent applications in each technology group

\begin{tabular}{|c|c|c|c|}
\hline Independent Variables & $\begin{array}{r}\text { All } \\
\text { Technologies } \\
\end{array}$ & $\begin{array}{r}\text { Supply } \\
\text { Technologies } \\
\end{array}$ & $\begin{array}{r}\text { Demand } \\
\text { Technologies }\end{array}$ \\
\hline \multirow[t]{2}{*}{ Energy Prices } & 0.125 & 1.080 & 0.801 \\
\hline & (2.862) & $(5.414)$ & $(6.000)$ \\
\hline \multirow[t]{2}{*}{ Lagged Energy Prices } & 0.462 & -0.887 & 0.268 \\
\hline & $(10.795)$ & $(-4.488)$ & (1.998) \\
\hline \multirow[t]{2}{*}{ Marginal Productivity of $R \& D$} & 0.259 & 0.115 & 1.865 \\
\hline & $(23.668)$ & (2.978) & $(40.352)$ \\
\hline \multirow[t]{2}{*}{ Time } & -0.152 & -0.425 & -0.306 \\
\hline & $(-74.959)$ & $(-52.123)$ & $(-33.571)$ \\
\hline \multirow[t]{2}{*}{ Government R\&D } & 0.010 & 0.018 & 0.039 \\
\hline & (7.279) & (3.033) & (8.047) \\
\hline \multirow[t]{2}{*}{ Lagged Government R\&D } & -0.016 & 0.247 & -0.041 \\
\hline & $(-11.551)$ & (4.639) & -8.255 \\
\hline \multirow{2}{*}{$\begin{array}{l}\text { Adjusted R-square } \\
\text { number of technology groups: }\end{array}$} & 0.775 & 0.950 & 0.782 \\
\hline & 17 & 9 & 8 \\
\hline \multicolumn{4}{|l|}{ t-stats below estimates } \\
\hline \multicolumn{4}{|l|}{$T=20$} \\
\hline Lagged & & & \\
\hline
\end{tabular}


Table 4 -- SUR Regression Results

Dependent variable: percentage of total domestic patent applications in each technology group

\begin{tabular}{|c|c|c|c|c|c|c|c|c|c|c|c|}
\hline Group & RBarSq & $\begin{array}{r}\text { Estimated } \\
\text { Correlation } \\
\end{array}$ & Constant & $\begin{array}{r}\text { Energy } \\
\text { Prices } \\
\end{array}$ & $\begin{array}{r}\text { Lagged } \\
\text { Energy } \\
\text { Prices } \\
\end{array}$ & $\begin{array}{r}\text { Marginal } \\
\text { y of } \\
\text { roductivit } \\
\text { Research }\end{array}$ & Time & $\begin{array}{r}\text { Federal } \\
\text { R\&D } \\
\text { Funding } \\
\end{array}$ & $\begin{array}{r}\text { Lagged } \\
\text { Federal } \\
\text { R\&D } \\
\text { Funding } \\
\end{array}$ & Other & Other \\
\hline Coal Liquefaction (1) & 0.858 & 0.459 & $\begin{array}{r}-9.857 \\
(-7.748)\end{array}$ & $\begin{array}{r}3.813 \\
(4.716)\end{array}$ & $\begin{array}{r}-2.303 \\
(-3.164)\end{array}$ & $\begin{array}{r}-0.900 \\
(-5.749)\end{array}$ & & $\begin{array}{r}-0.052 \\
(-1.887)\end{array}$ & $\begin{array}{r}0.015 \\
(0.563)\end{array}$ & & \\
\hline Coal Gasification (1) & 0.913 & 0.573 & $\begin{array}{r}-7.979 \\
(-7.925)\end{array}$ & $\begin{array}{r}3.047 \\
(4.833)\end{array}$ & $\begin{array}{r}-2.927 \\
(-4.934)\end{array}$ & $\begin{array}{r}-0.053 \\
(-0.595)\end{array}$ & & $\begin{array}{r}-0.013 \\
(-0.721)\end{array}$ & $\begin{array}{r}0.055 \\
(2.864)\end{array}$ & & \\
\hline Solar Energy (2) & 0.880 & -0.162 & $\begin{array}{r}-5.124 \\
(-2.095)\end{array}$ & $\begin{array}{r}7.215 \\
(3.510)\end{array}$ & $\begin{array}{r}-7.810 \\
(-3.562)\end{array}$ & $\begin{array}{r}0.601 \\
(2.782)\end{array}$ & & $\begin{array}{r}-0.031 \\
(-0.581)\end{array}$ & $\begin{array}{r}0.157 \\
(2.487)\end{array}$ & & \\
\hline Solar Batteries (2) & 0.983 & -0.135 & $\begin{array}{r}-9.805 \\
(-14.706)\end{array}$ & $\begin{array}{r}3.256 \\
(4.982)\end{array}$ & $\begin{array}{r}-1.307 \\
(-2.320)\end{array}$ & $\begin{array}{r}1.378 \\
(15.499)\end{array}$ & & $\begin{array}{r}0.018 \\
(1.146)\end{array}$ & $\begin{array}{r}0.052 \\
(3.598)\end{array}$ & & \\
\hline Fuel Cells (3) & 0.990 & -0.098 & $\begin{array}{r}-5.216 \\
(-1.009)\end{array}$ & $\begin{array}{r}-0.896 \\
(-1.245)\end{array}$ & $\begin{array}{r}2.502 \\
(4.551)\end{array}$ & $\begin{array}{r}0.249 \\
(2.379)\end{array}$ & & & & $\begin{array}{c}-1.4191^{A} \\
(-1.418)\end{array}$ & \\
\hline Wind Power (3) & 0.988 & -0.023 & $\begin{array}{l}24.502 \\
(7.049)\end{array}$ & $\begin{array}{r}4.601 \\
(3.520)\end{array}$ & $\begin{array}{r}0.062 \\
(0.048)\end{array}$ & & $\begin{array}{r}-10.475 \\
(-14.061)\end{array}$ & $\begin{array}{r}0.057 \\
(3.263)\end{array}$ & $\begin{array}{r}-0.012 \\
(-0.716)\end{array}$ & & \\
\hline Geothermal (3) & 0.991 & -0.687 & $\begin{array}{r}2.523 \\
(0.621)\end{array}$ & $\begin{array}{r}9.729 \\
(8.893)\end{array}$ & $\begin{array}{r}-7.695 \\
(-7.070)\end{array}$ & & $\begin{array}{r}-3.898 \\
(-4.505)\end{array}$ & $\begin{array}{r}0.052 \\
(2.010)\end{array}$ & $\begin{array}{r}-0.041 \\
(-2.449)\end{array}$ & & \\
\hline Waste Fuel (3) & 0.953 & -0.021 & $\begin{array}{l}-20.460 \\
(-6.933)\end{array}$ & $\begin{array}{r}5.482 \\
(2.405)\end{array}$ & $\begin{array}{r}-0.721 \\
(-0.294)\end{array}$ & $\begin{array}{r}0.296 \\
(1.390)\end{array}$ & & $\begin{array}{r}0.019 \\
(0.603)\end{array}$ & $\begin{array}{r}-0.122 \\
(-3.480)\end{array}$ & $\begin{array}{l}-0.5654^{B} \\
(-10.784)\end{array}$ & $\begin{array}{r}-0.0089^{C} \\
(-0.083)\end{array}$ \\
\hline Other Supply Technologies (2) & 0.982 & -0.490 & $\begin{array}{l}41.218 \\
(9.157) \\
\end{array}$ & $\begin{array}{r}-3.489 \\
(-4.069) \\
\end{array}$ & $\begin{array}{r}1.017 \\
(1.282) \\
\end{array}$ & & $\begin{array}{r}-10.248 \\
(-10.387) \\
\end{array}$ & $\begin{array}{r}0.192 \\
(7.418) \\
\end{array}$ & $\begin{array}{r}-0.032 \\
(-1.495) \\
\end{array}$ & & \\
\hline Waste Heat (4) & 0.972 & -0.127 & $\begin{array}{r}-11.680 \\
(-10.603)\end{array}$ & $\begin{array}{r}0.024 \\
(0.027)\end{array}$ & $\begin{array}{r}2.310 \\
(1.966)\end{array}$ & $\begin{array}{r}1.799 \\
(6.302)\end{array}$ & & $\begin{array}{r}0.161 \\
(4.392)\end{array}$ & $\begin{array}{r}-0.186 \\
(-3.518)\end{array}$ & & \\
\hline Heat Exchange -- CLS62 (4) & 0.984 & -0.246 & $\begin{array}{r}-4.562 \\
(-1.998)\end{array}$ & $\begin{array}{r}-0.513 \\
(-0.746)\end{array}$ & $\begin{array}{r}-0.715 \\
(-1.049)\end{array}$ & & $\begin{array}{r}-0.314 \\
(-0.672)\end{array}$ & $\begin{array}{r}0.006 \\
(0.301)\end{array}$ & $\begin{array}{r}0.047 \\
(2.100)\end{array}$ & & \\
\hline Heat Exchange -- CLS165 (4) & 0.937 & 0.266 & $\begin{array}{r}-5.482 \\
(-5.110)\end{array}$ & $\begin{array}{r}2.024 \\
(2.426)\end{array}$ & $\begin{array}{r}-1.696 \\
(-1.298)\end{array}$ & $\begin{array}{r}1.434 \\
(1.694)\end{array}$ & & $\begin{array}{r}-0.062 \\
(-3.317)\end{array}$ & $\begin{array}{r}0.067 \\
(1.408)\end{array}$ & & \\
\hline Heat Pumps (4) & 0.907 & 0.088 & $\begin{array}{r}-7.548 \\
(-5.220)\end{array}$ & $\begin{array}{r}1.044 \\
(0.658) \\
\end{array}$ & $\begin{array}{r}-1.297 \\
(-0.824) \\
\end{array}$ & $\begin{array}{r}0.208 \\
(1.336) \\
\end{array}$ & & $\begin{array}{r}-0.014 \\
(-0.295) \\
\end{array}$ & $\begin{array}{r}0.057 \\
(1.064) \\
\end{array}$ & & \\
\hline Stirling Engines (4) & 0.988 & -0.081 & $\begin{array}{r}-11.860 \\
(-26.584)\end{array}$ & $\begin{array}{r}3.174 \\
(6.691)\end{array}$ & $\begin{array}{r}-0.541 \\
(-1.147)\end{array}$ & $\begin{array}{r}0.469 \\
(7.822)\end{array}$ & & $\begin{array}{r}-0.065 \\
(-5.490)\end{array}$ & $\begin{array}{r}-0.004 \\
(-0.261)\end{array}$ & & \\
\hline Continuous Casting (4) & 0.974 & 0.051 & $\begin{array}{r}10.918 \\
(8.285)\end{array}$ & $\begin{array}{r}7.286 \\
(16.421)\end{array}$ & $\begin{array}{r}-1.072 \\
(-2.170)\end{array}$ & $\begin{array}{r}-0.670 \\
(-11.700)\end{array}$ & & & & $\begin{array}{r}-17.0192^{\mathrm{D}} \\
(-28.921)\end{array}$ & $\begin{array}{c}10.6443^{\mathrm{E}} \\
(31.653)\end{array}$ \\
\hline Aluminum -- Electroytic (3) & 0.922 & 0.213 & $\begin{array}{l}17.600 \\
(3.086)\end{array}$ & $\begin{array}{r}1.608 \\
(1.205)\end{array}$ & $\begin{array}{r}3.126 \\
(2.314)\end{array}$ & & $\begin{array}{r}-9.052 \\
(-5.773)\end{array}$ & & & & \\
\hline Other Demand Technologies (4) & 0.995 & -0.477 & $\begin{array}{l}-14.110 \\
(-6.691)\end{array}$ & $\begin{array}{r}0.041 \\
(0.099)\end{array}$ & $\begin{array}{r}0.167 \\
(0.376)\end{array}$ & & $\begin{array}{r}1.339 \\
(2.835)\end{array}$ & $\begin{array}{r}0.003 \\
(0.225)\end{array}$ & $\begin{array}{r}0.010 \\
(0.700)\end{array}$ & & \\
\hline
\end{tabular}

t-stats below estimates

$N=20$

Energy price used: (1) Petroleum, (2) Total, (3) End Users of Electricity, (4) Industrial

Other variables used: A: excess capacity of utilities, B: price of waste for fuel, C: lagged price of waste for fuel, D: price of steel ore, E: lagged price of steel ore 
Table 5 -- Summary of Induced Innovation SUR

Regression Results

\begin{tabular}{|c|c|c|c|c|}
\hline \multirow[b]{2}{*}{ independent variable: } & \multicolumn{4}{|c|}{ coefficient $>0$} \\
\hline & $p \geq .99$ & $\begin{array}{r}.99> \\
p \geq .95\end{array}$ & $\begin{array}{r}.95> \\
\mathrm{p} \geq .90\end{array}$ & insig. \\
\hline Energy Prices & 8 & 2 & 0 & 4 \\
\hline $\begin{array}{l}\text { Lagged Energy } \\
\text { Prices }\end{array}$ & 1 & 1 & 1 & 3 \\
\hline Federal R\&D & 3 & 0 & 1 & 4 \\
\hline \multirow[t]{3}{*}{ Lagged Federal R\&D } & 2 & 2 & 0 & 4 \\
\hline & \multicolumn{4}{|c|}{ coefficient $<0$} \\
\hline & $p \geq .99$ & $\begin{array}{r}.99> \\
p \geq .95\end{array}$ & $\begin{array}{r}.95> \\
\mathrm{p} \geq .90\end{array}$ & insig. \\
\hline Energy Prices & 1 & 0 & 0 & 2 \\
\hline $\begin{array}{l}\text { Lagged Energy } \\
\text { Prices }\end{array}$ & 4 & 2 & 0 & 5 \\
\hline Federal R\&D & 2 & 0 & 1 & 3 \\
\hline \multirow[t]{3}{*}{ Lagged Federal R\&D } & 2 & 1 & 0 & 3 \\
\hline & \multicolumn{4}{|c|}{ Pattern of signs } \\
\hline & ++ & +- & + & -- \\
\hline Energy Prices & 4 & 10 & 2 & 1 \\
\hline $\begin{array}{l}\text { Lagged Energy } \\
\text { Prices }\end{array}$ & $\Sigma>0$ & 8 & 1 & \\
\hline Federal R\&D & 3 & 5 & 5 & 1 \\
\hline Lagged Federal R\&D & $\Sigma>0$ & 3 & 4 & \\
\hline
\end{tabular}




\section{Table 6 -- Pooled Regression Results}

Dependent variable: percentage of total domestic patent applications in each technology group

Results without controling for the productivity of R\&D

A. No control for productivity of $R \& D$ (no time trend or productivity estimates)

\begin{tabular}{|c|c|c|c|}
\hline Independent Variables & $\begin{array}{r}\text { All } \\
\text { Technologies } \\
\end{array}$ & $\begin{array}{r}\text { Supply } \\
\text { Technologies } \\
\end{array}$ & $\begin{array}{r}\text { Demand } \\
\text { Technologies } \\
\end{array}$ \\
\hline Energy Prices & $\begin{array}{r}1.289 \\
(13.687)\end{array}$ & $\begin{array}{r}0.903 \\
(2.251)\end{array}$ & $\begin{array}{r}0.008 \\
(0.032)\end{array}$ \\
\hline Lagged Energy Prices & $\begin{array}{r}-0.769 \\
(-8.364)\end{array}$ & $\begin{array}{r}-0.328 \\
(-0.859)\end{array}$ & $\begin{array}{r}0.104 \\
(0.412)\end{array}$ \\
\hline Government R\&D & $\begin{array}{r}-0.009 \\
(-3.252)\end{array}$ & $\begin{array}{r}0.020 \\
(2.119)\end{array}$ & $\begin{array}{r}0.034 \\
(3.491)\end{array}$ \\
\hline Lagged Government R\&D & $\begin{array}{r}0.007 \\
(2.635) \\
\end{array}$ & $\begin{array}{r}0.007 \\
(0.888) \\
\end{array}$ & $\begin{array}{l}-0.015 \\
-1.693 \\
\end{array}$ \\
\hline $\begin{array}{l}\text { Adjusted R-square } \\
\text { number of technology groups: }\end{array}$ & $\begin{array}{r}0.866 \\
17\end{array}$ & $\begin{array}{r}0.840 \\
9\end{array}$ & $\begin{array}{r}0.944 \\
8\end{array}$ \\
\hline 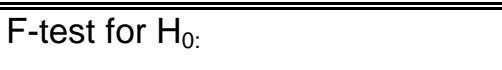 & & & \\
\hline Producitivity of $R \& D=$ time $=0$ & 3149.192 & 1358.653 & 1005.002 \\
\hline
\end{tabular}

B. Time trend used instead of productivity parameters

\begin{tabular}{|c|c|c|c|}
\hline Independent Variables & $\begin{array}{r}\text { All } \\
\text { Technologies }\end{array}$ & $\begin{array}{r}\text { Supply } \\
\text { Technologies }\end{array}$ & $\begin{array}{r}\text { Demand } \\
\text { Technologies }\end{array}$ \\
\hline \multirow[t]{2}{*}{ Energy Prices } & 10 & 10 & $\begin{array}{ll}-0.267 \\
\end{array}$ \\
\hline & $(40.972)$ & $(5.177)$ & $(-1.549)$ \\
\hline \multirow[t]{2}{*}{ Lagged Energy Prices } & -0.459 & 0.355 & -2.329 \\
\hline & $(-10.051)$ & (1.135) & $(-13.333)$ \\
\hline \multirow[t]{2}{*}{ Time } & 0.556 & -0.749 & -0.659 \\
\hline & (9.574) & $(-2.371)$ & $(-2.856)$ \\
\hline \multirow[t]{2}{*}{ Government R\&D } & -0.032 & 0.012 & 0.281 \\
\hline & $(-20.723)$ & $(1.651)$ & $(5.402)$ \\
\hline \multirow[t]{2}{*}{ Lagged Government R\&D } & -0.005 & -0.034 & 0.112 \\
\hline & $(-3.694)$ & $(-5.126)$ & 22.621 \\
\hline Adjusted R-square & $\overline{-0.683}$ & 0.695 & 0.232 \\
\hline number of technology groups: & 17 & 9 & 8 \\
\hline
\end{tabular}

t-stats below estimates

$T=20$ 
Figure 1 - The Innovations Possibilities Frontier

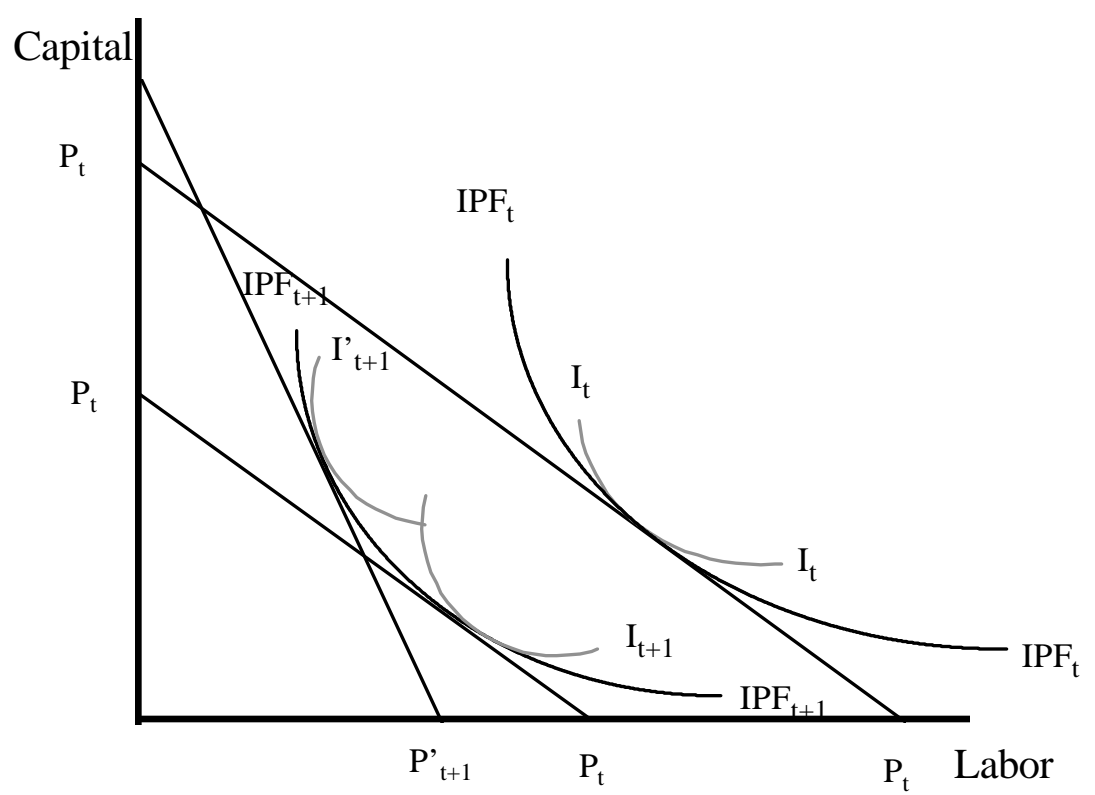

Note: In this diagram, $P$ does not represent actual prices, but is simply a label for the relative price lines.

The figure presents an example of the innovation possibilities frontier. At time $t$, the IPF is represented by $\mathrm{IPF}_{\mathrm{t}}$. It is the envelope of several possible isoquants, each relating to a different technology. The actual technology chosen depends on the relative prices. $I_{t}$ represents the isoquant chosen with prices represented by the price line $\mathrm{P}_{t} \mathrm{P}_{t}$. In the next period, technological advances move the IPF to $\mathrm{IPF}_{\mathrm{t}+1}$. If relative prices remain the same, the new technology is represented by isoquant $\mathrm{I}_{\mathrm{t}+1}$. However, if the price of labor increases, as shown here, a different isoquant, $I_{t+1}$, is chosen instead. The new prices lead to technological change that uses less labor and more capital then before. 
Figure 2- Patent Applications by U.S. Inventors

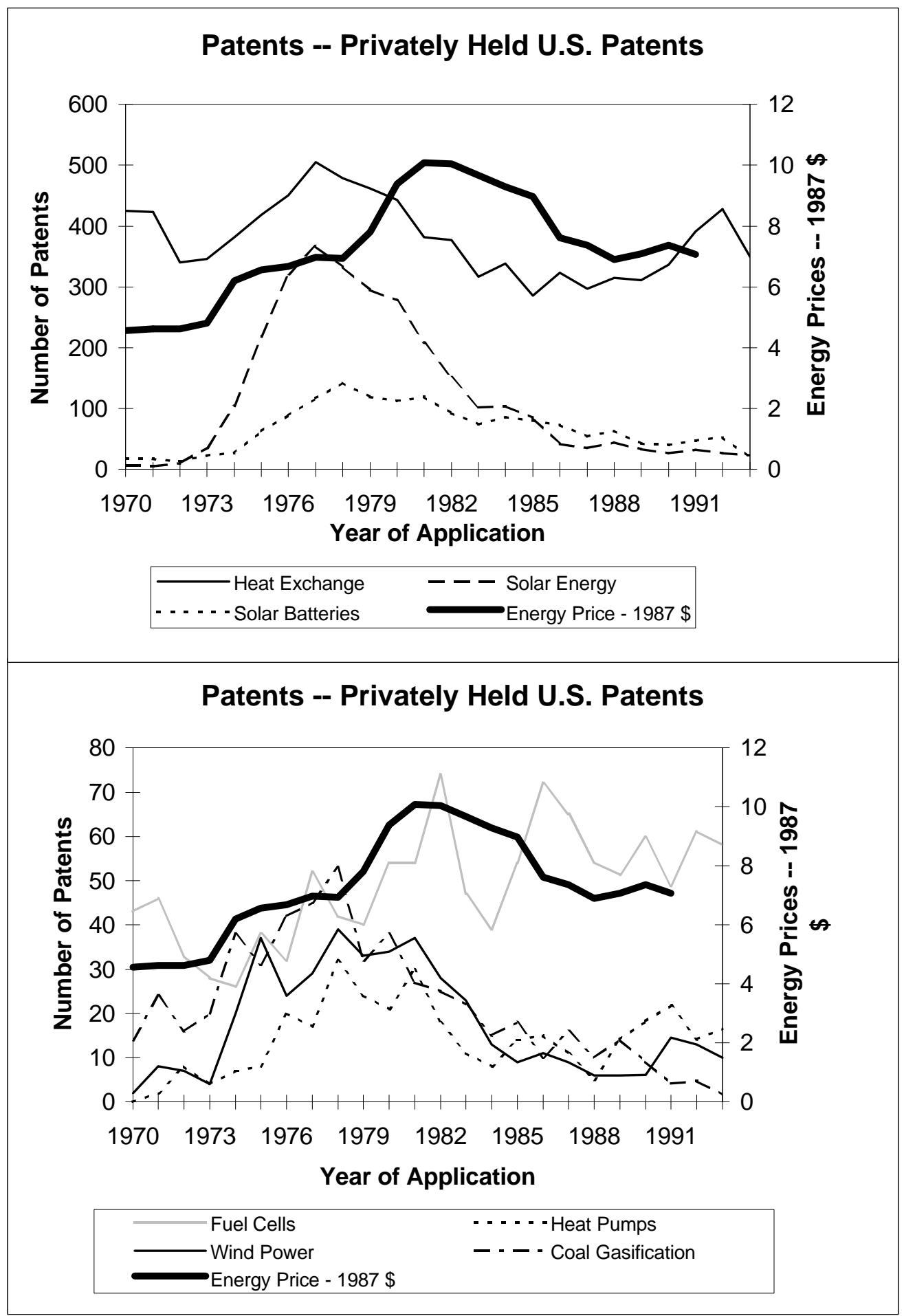

NOTES: Energy prices are the cost per million Btu of energy consumption, in 1987 dollars. 
Figure 3 - Probability of Citation

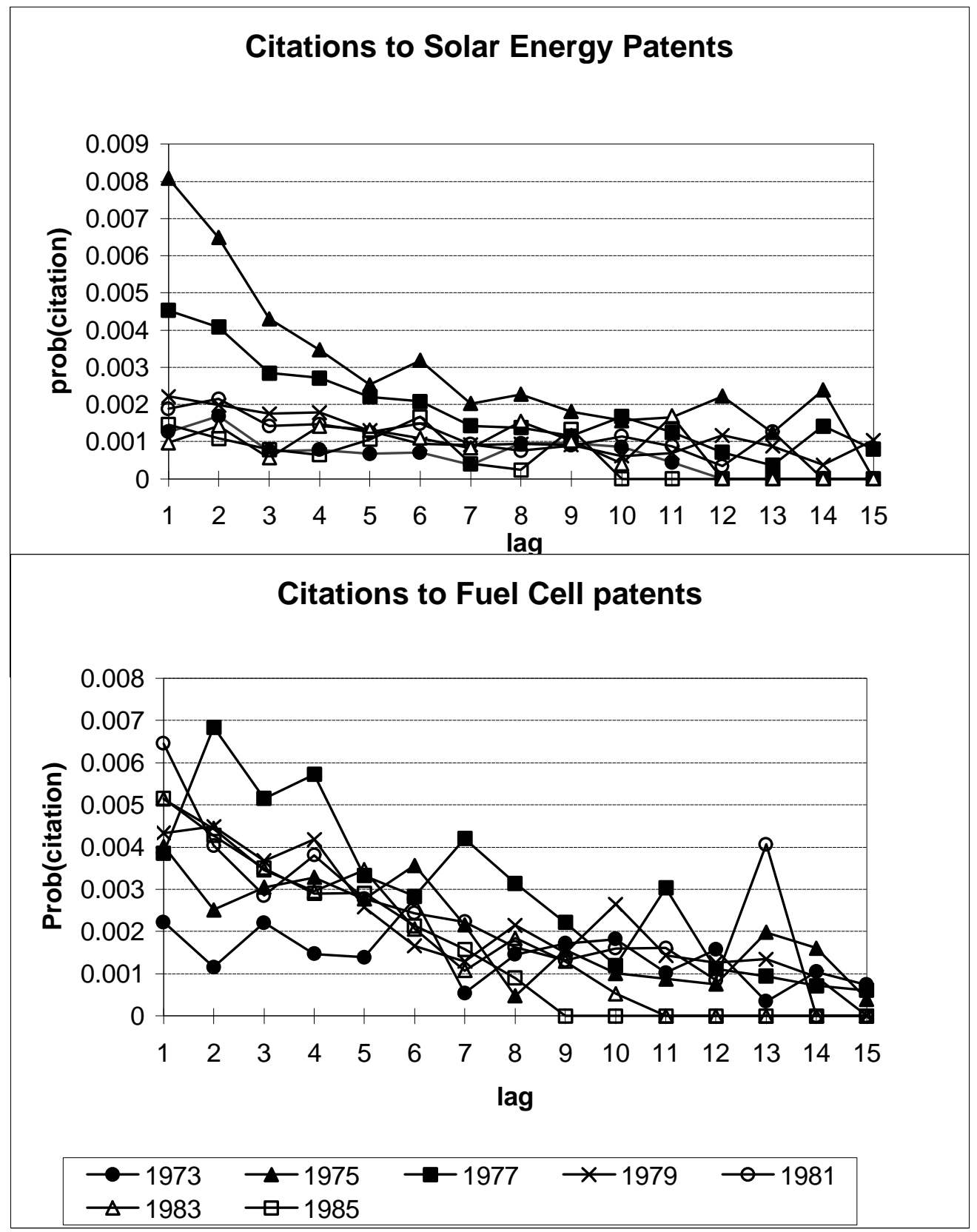

The figure presents the probability that patents granted in year $\mathrm{x}$ will be cited by patents applied for in following years. Each line represents the patents granted in a different year. The $\mathrm{x}$-axis is the number of years since the patent was granted. 
Figure 4 - Productivity Estimates: Citations to Patents in Same Technology Group

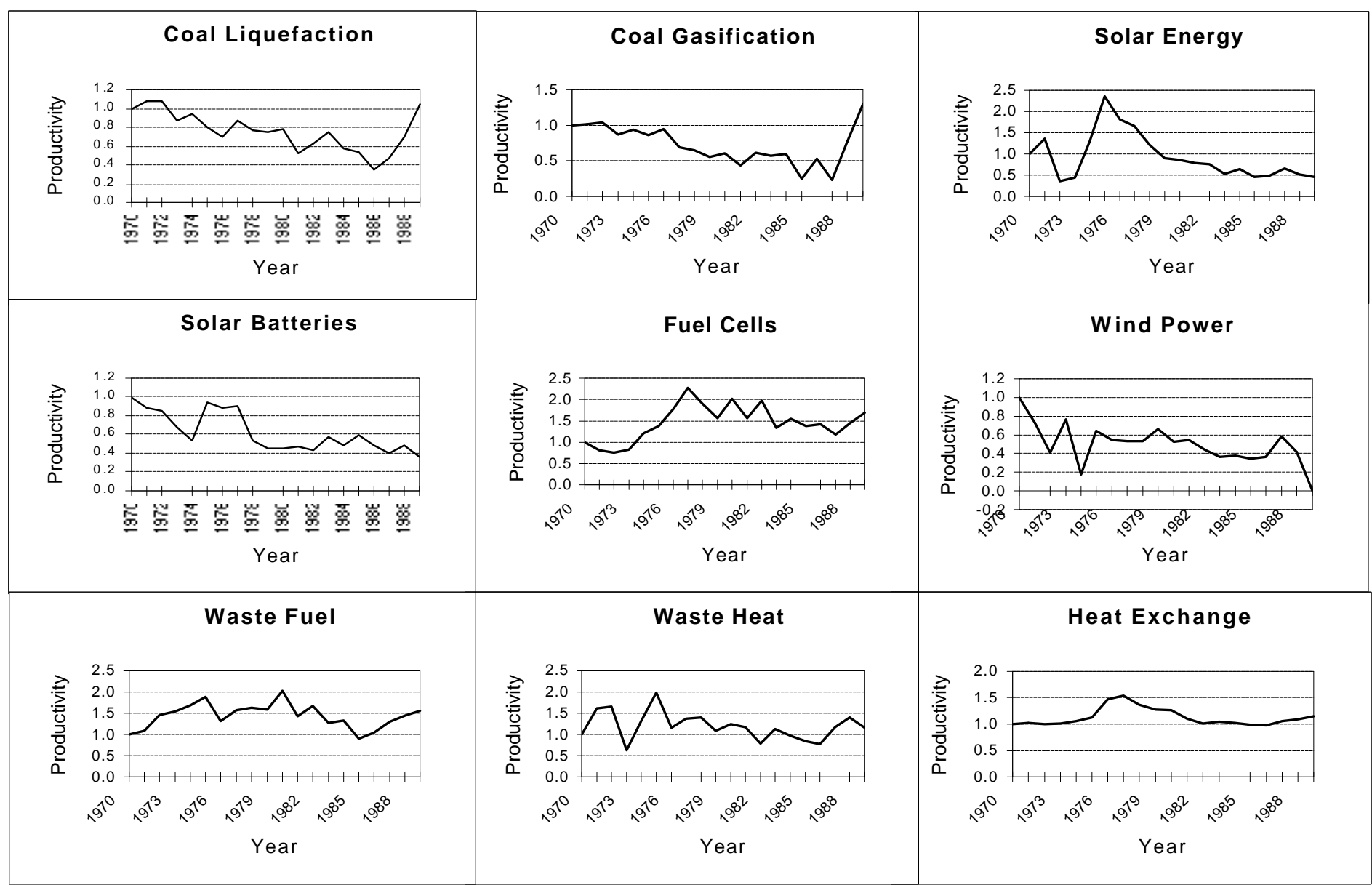

Figures show the productivity estimates for each technology group, with 1970 normalized to 1 in each case. Note that, for most technologies, there is a declining trend to the estimates, suggesting diminishing returns to research over time. This will be explored more carefully in section $\mathrm{V}$.

Figure is continued on the next page. 
Figure 4 - Productivity Estimates: Citations to Patents in Same Technology Group

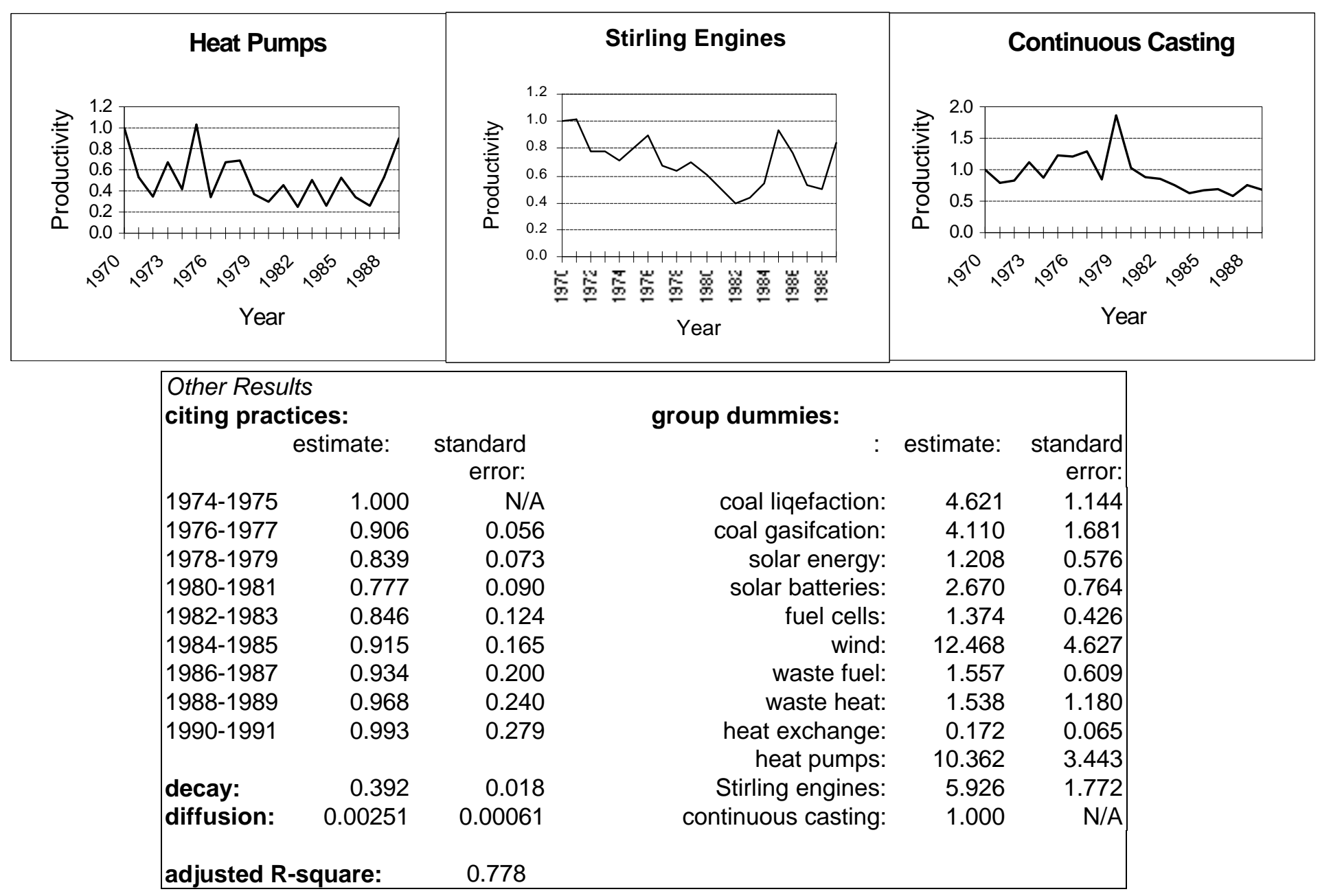

Figures show the productivity estimates for each technology group, with 1970 normalized to 1 in each case. Note that, for most technologies, there is a declining trend to the estimates, suggesting diminishing returns to research over time. This will be explored more carefullv in section $\mathrm{V}$. 


\section{Figure 5 -- Energy Prices By Fuel Type}

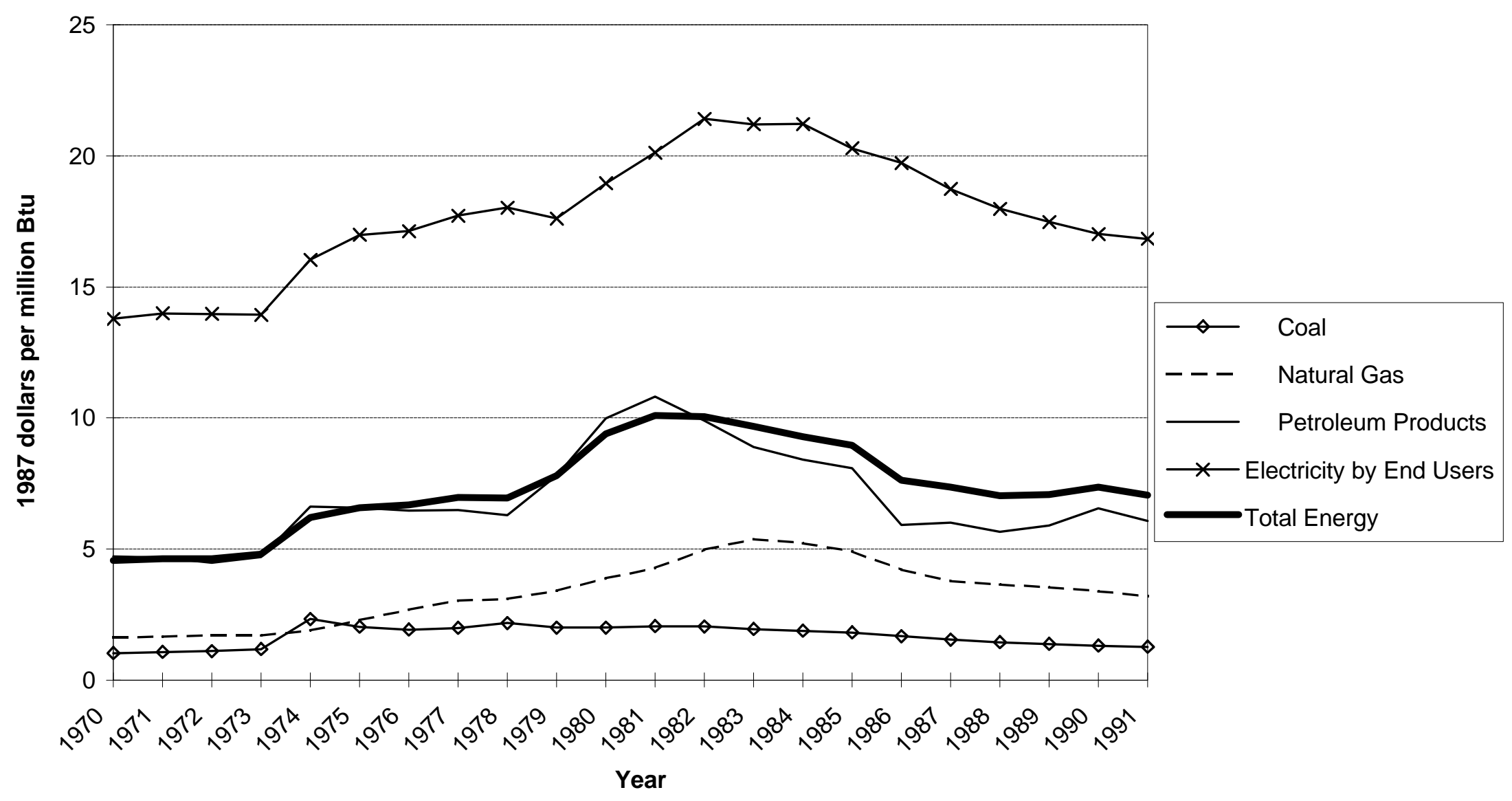

The figure shows energy prices in 1987 dollars per million Btu of energy consumed. Total energy is this value for all energy sources consumed. The other plots are for individual energy sources. 